University of Tulsa College of Law

TU Law Digital Commons

Articles, Chapters in Books and Other Contributions to Scholarly Works

2017

\title{
Coercion, Fraud, and What is Wrong With Blackmail
}

Stephen Galoob

Follow this and additional works at: https://digitalcommons.law.utulsa.edu/fac_pub

Part of the Jurisprudence Commons

\section{Recommended Citation}

Coercion, Fraud, and What Is Wrong With Blackmail, 22 Leg. Theory 22. doi:10.1017/S1352325216000082

This Article is brought to you for free and open access by TU Law Digital Commons. It has been accepted for inclusion in Articles, Chapters in Books and Other Contributions to Scholarly Works by an authorized administrator of TU Law Digital Commons. For more information, please contact daniel-bell@utulsa.edu. 
Coercion, Fraud, and What Is Wrong With Blackmail

\author{
COERCION, FRAUD, AND WHAT IS WRONG WITH BLACKMAIL \\ forthcoming in LEGAL THEORY \\ Stephen Galoob \\ University of Tulsa College of Law
}

\begin{abstract}
Several theorists argue that blackmail is morally wrong because the blackmail proposal is coercive. These coercion-based views are promising but incomplete. A full explanation of blackmail's immorality must address both the blackmail proposal and the blackmail agreement. I defend what I call the complex account, on which blackmail is morally wrong because blackmail proposals are coercive and blackmail agreements are fraudulent. The complex account avoids difficulties that beset other coercion-based views and provides a stronger case for why blackmail should be criminalized.
\end{abstract}

Several scholars argue that blackmail is morally wrong because it is coercive. ${ }^{1}$ These coercion-based views focus on the blackmail proposal, the blackmailer's offer or threat to act in a certain way (paradigmatically, to disclose information whose revelation would

* Thanks to, among others, Chuck Adams, Craig Agule, Brian Berkey, Mitch Berman, Robert Butkin, Michael Cahill, Vincent Chiao, Russell Christopher, Niko Cornell, Mihailis Diamantis, Mindy Galoob, Andrew Gold, Stuart Green, Sam Halabi, Adam Hill, Robert Hughes, Eric Johnson, Adam Kolber, Grant Lamond, Ethan Leib, Phil Nichols, Japa Pallikkathayil, David Rubenstein, Alex Sarch, Naomi Schoenbaum, Amy Sepinwall, James Shaw, Bob Spoo, Simon Stern, Rob Weber, Ray Yasser, and an anonymous reviewer for LEGAL THEORY. Thanks also to audiences at the Oklahoma Junior Scholars Conference, the Washington University Law School Junior Scholars Conference, the NYU Criminal Law Theory colloquium, and the Zicklin Center Normative Business Ethics workshop at the University of Pennsylvania's Wharton School. The animating example of this paper was inspired by a comment made by Merlin Holland, Oscar Wilde's grandson and biographer, during the Oscar Wilde and the Law conference at the University of Tulsa College of Law in the fall of 2013.

${ }^{1}$ James R. Shaw, The Morality of Blackmail, 40 PHIL. \& PUB. AfF. 165 (2012); Mitchell Berman, The Evidentiary Theory of Blackmail: Taking Motives Seriously, 65 U. CHI. L. REV. 795 (1998); Mitchell Berman, Blackmail, in THE OXFORD HANDBOOK ON THE Philosophy of the Criminal Law 37-106 (John Deigh \& David Dolinko eds., 2011); Dan Fitzpatrick, The Philosophy of Blackmail: Indecent Offers or Coercive Proposals, 29 J. Soc. PHIL. 37 (1998); Michael Gorr, Liberalism and the Paradox of Blackmail, 21 PHIL. \& Pub. AfF. 43 (1992); Grant Lamond, Coercion, Threats, and the Puzzle of Blackmail, in HARM AND CUlPABILITY 215-238 (A.P. Simester \& A.T.H. Smith eds., 1996). 
harm or embarrass the target of blackmail) unless the target agrees to the blackmailer's demands. On James Shaw's simple account, the typical blackmail proposal wrongs the target by unjustifiably impinging his authority to decide what to do.

Coercion-based views are a genuine breakthrough for explaining the immorality of blackmail, which is one of the most-discussed questions in criminal law. Yet although coercion-based views capture a core aspect of why blackmail is wrong, they are incomplete. They do not explain everything that is wrong with blackmail, nor do they offer a fully convincing explanation of why blackmail should be criminalized. Meeting these challenges requires analyzing the blackmail agreement as well as the blackmail proposal.

In this article I defend the complex account of why blackmail is wrong. On this view, blackmail is typically wrong because the blackmail proposal is coercive and the agreement contemplated in that proposal is fraudulent. The complex account is a friendly amendment to coercion-based views like Shaw's simple account. Compared to alternatives, the complex account provides a more complete explanation of why blackmail is immoral and a stronger case for why blackmail should be criminally prohibited.

Section I summarizes Shaw's simple account and raises some difficulties that apply both to this view and to coercion-based views more broadly. Section II articulates and defends the complex account. I provide a contingent argument that blackmail is appropriately criminalized because many blackmail agreements are fraudulent, as well as a more categorical argument that blackmail agreements are fraudulent in any just legal system. The complex account preserves the strengths of Shaw's simple account while 
avoiding its difficulties. In the Conclusion, I discuss some general implications of the complex account for theorizing about blackmail. Appendix 1 shows how the complex account can be used to supplement another coercion-based view, Mitchell Berman's evidentiary theory of blackmail.

\section{WHY BLACKMAIL IS WRONG: COERCION}

Subsection A analyzes the strengths of coercion-based views, focusing on Shaw's simple account. I focus on the simple account not to endorse it but because, along with Berman's evidentiary theory, it is the best developed coercion-based view. Subsection B describes some difficulties facing the simple account and many other theories of why blackmail is wrong.

\section{A. Shaw's Simple Account}

To orient the discussion, consider the following episode, "probably the most famous blackmail attempt in history,", from the life of Oscar Wilde. William Allen, a professional blackmailer, obtained several letters from Wilde to Lord Alfred Douglas that referenced Wilde's sexual conduct with young men. Wilde later testified that Allen approached him by noting that "a very curious construction could be put upon" one of Wilde's letters to Douglas. Wilde recounted the following exchange:

"Art is rarely intelligible to the criminal classes." [Allen] said, "A man offered me $£ 60$ for it." [Wilde then] said to [Allen], "If you take my advice you will go to that man and sell my letter to him for £6o. I myself have never received so large a sum for any prose work of that length; but I am glad to find that there is some one in England who considers a letter of mine worth $£ 60 . " 3$

Once it became clear that Wilde would not agree to the proposal, Allen "changed his manner" and admitted living in desperate poverty. Wilde gave Allen a half-sovereign out of pity, and Allen later returned the incriminating letter to Wilde.

\footnotetext{
2 Angus Mclaren, Sexual Blackmail: A Modern History (2002), at 22.

${ }^{3}$ Richard EllmanN, The Trial of OsCar Wilde (1996), at 419.
} 
From Wilde's case, we can identify two notions that are important for analyzing the wrongfulness of blackmail. First, the blackmail proposal is the blackmailer's indication of an intention to do X (for example, to disclose a secret of the target) unless the target and blackmailer enter into an agreement under which the target agrees to do Y (paradigmatically, to pay money to the blackmailer) and the blackmailer agrees not to do $\mathrm{X}$. In order for the proposal to be an instance of blackmail, the blackmailer's X-ing must have the antecedent deontic status of being permissible. ${ }^{4}$

In Wilde's case, the blackmail proposal was Allen's indication of his intent to disclose the incriminating contents of Wilde's letter if Wilde did not pay Allen at least $£ 60$. Implicit in this proposal is that Allen would agree not to disclose the contents of Wilde’s letter if Wilde agreed to pay Allen at least $£ 60$. Assume for the sake of argument that Allen's disclosing the contents of Wilde's letter would have the antecedent status of being permissible, since it would be neither forbidden nor required. ${ }^{5}$

Second, we can preliminarily define the blackmail agreement or exchange ${ }^{6}$ as the transaction, prompted by the blackmail proposal, by which the target agrees (and therefore incurs an obligation) to do Y, the blackmailer agrees (and incurs an obligation) not to do $\mathrm{X}$, and these obligations interdepend in the way that is constitutive of

${ }^{4}$ The antecedent permissibility of doing $\mathrm{X}$ is sometimes said to differentiate blackmail from extortion, where the action referenced in the proposal is antecedently impermissible. See Leo Katz, Blackmail and Other Forms of Arm-Twisting, 141 U. PA. L. REV. 1567 (1993), at 1599.

${ }^{5}$ Some might dispute this assumption on the grounds that since sodomy was a crime in Britain at the time of Allen's proposal, Allen's failure to disclose would have violated a moral or legal duty to disclose information of criminal wrongdoing to authorities. JOEL FEINBERG, HARMLESS WrONGDOING (1988), at 241-245.

${ }^{6}$ The term blackmail exchange is more prominent in the literature, but the term blackmail agreement seems more accurate. I use these terms synonymously. 
agreements. ${ }^{7}$ Not all blackmail proposals lead to agreements. For example, Allen and Wilde did not enter into a blackmail agreement. In refusing Allen's proposal, Wilde did not put himself under a new obligation to pay Allen any sum. Likewise, because Wilde refused his proposal, Allen incurred no new obligation to keep the contents of Wilde's letter secret.

Wilde's case shows how the existence of a blackmail agreement depends on the interrelated intentions and behaviors of the parties. In the wake of a blackmail proposal, the blackmailer might refrain from doing $\mathrm{X}$ and the target might do $\mathrm{Y}$. Yet there is no agreement if these actions do not respond to the blackmail proposal. For example, Wilde actually paid Allen some money, but because he felt sorry for Allen rather than in exchange for Allen's silence. Wilde's action was occasioned by Allen's proposal but was not a response to it. Likewise, Allen handed over Wilde's letter, but not in exchange for Wilde's payment. Thus Wilde and Allen did not enter into a blackmail agreement, even though each behaved in a way (Wilde paying Allen money, Allen handing over Wilde's letter) consistent with them having entered into such an agreement.

Shaw's simple account aims to explain why blackmail is morally wrong. In general, he contends, a "coercive announcement" like the blackmail proposal is morally “impermissible if it attaches a sanction to an option in an agent's deliberation that the agent is entitled to deliberate about." ${ }^{\prime 8}$ Shaw does not offer a full description of "when an

${ }^{7}$ Hanoch Sheinman, Agreement as Joint Promise, in Promises ANd AgreEMENTs: PHILOSOPHICAL ESSAYS 365 (Hanoch Sheinman ed., 2011), at 369-370. I refine this preliminary definition in Section II.A.

${ }^{8}$ Shaw, supra note 1 , at 166. 
agent is entitled to deliberate about an available action without sanction." ${ }^{9}$ Rather, he identifies a common feature: if I am entitled to decide whether to perform an action, then you would wrong me by attaching sanctions to my performance of that action in a way that interferes with my deliberation on this matter. ${ }^{10}$ If you would wrong me by interfering with matters over which I have the right to deliberate, then you would also wrong me by communicating that you will interfere with my deliberation. ${ }^{11}$

The simple account therefore holds not only that blackmail is wrong but also that it wrongs the target distinctly by impinging on his or her deliberative authority. This infringement is significant even if it does not also set back the target's interests overall. In the paradigmatic blackmail case, the target has the "default discretionary authority" to "go about [his or her] business without compensating the blackmailer." 12 By making the proposal, the blackmailer attempts to "undu[ly] influence[]" the target's exercising this authority by raising the costs of exercising it. ${ }^{13}$ Although Shaw does not use these terms, the wrongfulness of this influence can be seen as a form of what Arthur Ripstein calls "usurpation." 14 In making the blackmail proposal, the blackmailer is a usurper because he

${ }^{9}$ Id. at 167.

${ }^{10} I d$.

${ }^{11} I d$. at 168 .

${ }^{12}$ Id. at 175.

${ }^{13}$ Id. at 177 .

14 Arthur Ripstein, Force And Freedom: Kant's Legal and Political Philosophy (2009), at 54. On Ripstein's Kantian view, "you are independent only if you are the one who decides what ends you will use your powers to pursue, as opposed to having someone else decide for you." Id. at 33. Someone else can interfere with your independence by either usurping or destroying your powers to set and pursue purposes. $I d$. at 43 . When someone usurps your powers, he "deprives you of the ability to be able to decline to pursue purposes unless you have set them.” Id. at 44. For Ripstein, usurping 
attempts to get the target to exercise his default discretionary authority for the

blackmailer's purposes. $^{15}$

This brief description of the simple account seems to raise a tension. On the definition offered above, the action referenced in the blackmail proposal is antecedently permissible. Yet the simple account suggests that the blackmail proposal renders doing X impermissible, which in turn renders impermissible the conditional proposal to do X. So, one might wonder, is doing $\mathrm{X}$ permissible, or is it not?

your powers amounts to "using" you, insofar as the usurpation renders your choice subject to someone else's will and deprives you of the "ability to decide what to do" for yourself. Id. Japa Pallikkathayil defends a similar notion of coercion as usurpation. See Japa Pallikkathayil, The Possibility of Choice: Three Accounts of the Problem with Coercion, 11 PHIL. IMPRINT 18 (2011).

"Usurpation" is not the only or even the most common way to construe the wrongfulness of coercion. Alternative accounts focus on different features, such as the ways that coercion negates reciprocity and therefore violates the target's moral equality; see, e.g., StePhen DARWALl, THE SECOND-PERSOn StANDPOINT (2006), at 22; or puts the target in a position "where her goals become self-undermining"; Saba Bazargan, Moral Coercion, 14 PHIL. IMPRINT 1 (2014), at 6; or constitutes an irresponsible act of reasoncreation by the coercer; A.J. Julius, The Possibility of Exchange, 12 POL. PHIL. \& ECON. 361 (2013), at 362-363; or brings about a relationship in which the target is dominated by the coercer; Scott Anderson, The Enforcement Approach to Coercion, 5 J. ETHICs \& Soc. PHIL. (2010); Niko Kolodny, What Makes Threats Wrong, forthcoming in ANALYTIC PHILOSOPHY); or wrongfully puts pressure on the target's will or liberty to do otherwise; Alan Wertheimer, COERCION (1987); Mitchell Berman, The Normative Functions of Coercion Claims, 8 LEGAL THEORY 45 (2002).

Coercion-based accounts of blackmail differ, inter alia, based on the notions of wrongful coercion that they utilize. For example, Lamond explains the wrongfulness of coercion in terms of domination: in coercing the target, the blackmailer attempts to obtain (over the target's objections or invalid consent) "whatever [he] demand[s]" of the target." Lamond, supra note 1, at 233-234. By contrast, Berman's evidentiary theory incorporates the "wrongful pressure" notion of coercion. See Berman, Blackmail, supra note 1, at 66-67. For Berman, blackmail proposals are coercive when the action referenced in the proposal would, if carried out, wrongfully set back certain of the target's interests, and the prospect of this wrongful harming exerts pressure on the target's liberty or will.

${ }^{15}$ RIPSTEIN, supra note 14, at 43. See also Lamond, supra note 1, at 219. 
Shaw resolves this tension by arguing that whether an agent acts permissibly can "be sensitive to the motives and values of that agent." ${ }^{16}$ Some object to this position generally, and for that reason would be inclined to reject the simple account. For the sake of argument, assume that intentions can bear directly on the permissibility of actions. However, based on this assumption, it is premature to say above that the $\mathrm{X}$-ing referenced in the blackmail proposal is antecedently permissible. More accurately, doing X could be permissible if it were done for the right reasons. However, after the blackmailer makes the proposal, it can be inferred that his later doing $\mathrm{X}$ would be impermissible because it would not be done for the right reasons. ${ }^{17}$

But how, exactly, does making the blackmail proposal indicate that the blackmailer's later doing $\mathrm{X}$ would not be done for the right reasons? To support this inference, Shaw identifies a "subtle form of moral turpitude" that he calls "impermissible disregard." 18 According to Shaw, you show impermissible disregard for my well-being by knowingly creating harms for me that are "not appropriately offset" by the value of "your own furthered ends," even if the creation of these harms could have been justified in furtherance of some worthwhile goal. ${ }^{19}$ In paradigmatic cases of informational blackmail, the target has a default discretionary authority regarding paying the blackmailer money and entering into an agreement with him. By proposing to release the information if the target refuses to enter into a blackmail agreement, the blackmailer attaches sanctions to the target's decisions regarding these issues. These actions attempt

\footnotetext{
${ }^{16}$ Shaw, supra note 1, at 171.

${ }^{17}$ Id. at 170-171; see also Berman, Blackmail, supra note 1, at 69-70.

${ }^{18}$ Shaw, supra note 1 , at 169.

${ }^{19}$ Id. at 170 .
} 
to usurp the target's deliberative authority, and they also manifest an impermissible lack of concern for his interests. ${ }^{20}$

The simple account can cleanly explain the wrong in Wilde's case. Allen's statement to Wilde implied that Allen would expose Wilde's letter unless Wilde entered into an agreement. The sexual behavior referenced in the letter was criminal in England at the time. Revelation of Wilde's secret would severely harm his reputation and, eventually, land him in prison. Wilde clearly had a general authority to decide whether to transfer funds to Allen. ${ }^{21}$ In making his proposal to Wilde, Allen attempted to take control Wilde's authority to make this decision. Although some considerations might have justified Allen in taking control of Wilde's authority in this domain, "that Allen wanted to get at least $£ 60$ " or "that Allen wanted to punish Wilde for refusing to enter into a blackmail agreement whereby Allen would have obtained $£ 60$ ” are insufficient reasons to do so.

The simple account appraises blackmail's wrongfulness in terms of the blackmail proposal. As Shaw notes, "[i]n the case of impermissible coercion, it is the announcement

\footnotetext{
${ }^{20} I d$. at 172 . Thus it is perhaps more accurate to characterize Shaw as offering a "usurpation and disregard" account of wrongful coercion-usurping someone's deliberative authority is what makes a proposal coercive, and the disregard animating the proposal is (at least part of) what makes the proposal wrongful. My contention that Shaw offers a "usurpation" account of wrongful coercion should be read to include this proviso.

${ }^{21}$ One might also contend, somewhat anachronistically, that Wilde had authority to decide whether to reveal information about his sexual behavior to the world. However, whether Allen's proposal is coercive does not depend on whether Wilde has the right to control the disclosure of this information. As noted above, Shaw sees the infringement of the target's default discretionary authority as sufficient to make the blackmail proposal wrong. Id. at 193. In other words, Allen's blackmail proposal would have been objectionably coercive even if Wilde had no entitlement regarding the disclosure of information about his sexual behavior.
} 
(prototypically) that constitutes the way of tampering with another's deliberation." ${ }^{22}$

Blackmail is coercive even if, as in Wilde's case, the proposal does not lead to an exchange and the blackmailer never makes good on his expressed intention to do X. The simple account thus captures the inchoate nature of blackmail, or the way the wrong of blackmailing is accomplished "upon issuance of the [blackmail] proposal" rather than upon execution of a blackmail agreement. ${ }^{23}$

In addition to capturing the inchoate nature of blackmail, the simple account has many other strengths. Like other coercion-based views, the simple account dissolves the so-called "paradox of blackmail," the question of how the blackmail proposal could be morally or legally impermissible when each of its components (the blackmailer's doing $\mathrm{X}$; the blackmailer and target entering into an agreement whereby the blackmailer is obligated not do $\mathrm{X}$ and the target is obligated to $\mathrm{Y}$ ) seems morally and legally permissible. ${ }^{24}$ The simple account also resolves the so-called "second paradox of

${ }^{22} I d$. at 177.

${ }^{23}$ Russell Christopher, A Political Theory of Blackmail: A Reply to Professor Dripps, 3 CRIM. L. \& PHIL. 261 (2009), 265. Most extant criminal laws construe blackmail as an inchoate crime, in that liability attaches on the making of the proposal (rather than when a blackmail agreement is reached). See James Lindgren, Unraveling the Paradox of Blackmail, 84 Colum. L. REV. 670 (1984), at 676 n. 31.

${ }^{24}$ Lindgren, supra note 23; Glanville Williams, Blackmail, 1954 CRIM. L. REV. 79 (1954), at 79-92, 162-172, 240-246. Others have contended that the legal version of the paradox is not strictly paradoxical, since many criminal offenses consist of components that are each morally and legally permitted. Michael Clark, There Is No Paradox of Blackmail, 54 ANALYSIS 54 (1994). The simple account provides an additional way to resolve the first paradox: there is no paradox because the blackmail proposal changes the status of doing $\mathrm{X}$ for the blackmailer. In making the proposal, the blackmailer both infringes the target's deliberative authority and makes it the case that future X-ing would manifest disregard for the target. 
blackmail," which asks why blackmailer-initiated proposals regarding doing X are morally impermissible whereas target-initiated proposals are not. ${ }^{25}$

\section{B. Three Difficulties}

Despite these strengths, Shaw's simple account faces several difficulties. These difficulties also apply to other coercion-based accounts as well as to a variety of approaches that explain the wrongfulness of blackmail on grounds other than coercion.

\section{The Ratification Objection}

One set of difficulties concerns how the creation of a blackmail agreement might affect the wrongfulness of the blackmail proposal. The simple account has no response to the argument that the objectionable features of the blackmail proposal can be obviated when the blackmailer and target enter into an agreement. This argument, which I call the ratification objection, holds that the creation of the agreement can (at least in some circumstances) obviate the wrong-making features of the proposal. ${ }^{26}$

${ }^{25}$ Sidney W. DeLong, Blackmailers, Bribe Takers, and the Second Paradox, 141 U. PA. L. REV. 1663 (1993). On the simple account, the blackmailer's announcement attempts to usurp the target's deliberative authority. If (as in the case of target-initiated proposals) there is no announcement by the blackmailer, then there is no attempt by the blackmailer to usurp this authority. A target-initiated proposal is an exercise of deliberative authority by the target rather than an attempted usurpation of that authority by the blackmailer. Shaw, supra note 1, at 178-179.

${ }^{26}$ The notion that a party's actions can ratify (and therefore validate) an otherwise invalid agreement is a staple of contract law. See Joseph M. Perillo \& John E. Murray, Jr. 1 CORBIN ON CONTRACTS $\S 1.6$ (2015) (in cases of voidable contracts, "the agreement may be made fully operative as against both of the parties, by the exercise of a power of ratification" by the "injured party with the power of avoidance").

A. John Simmons's discussion of loyalty oaths and refugees is based on a version of the ratification objection. A state's demand that people obey its laws is, for Simmons, a paradigmatic example of coercion, since it involves taking control over subjects' individual authority to decide which obligations will apply to them. Thus a state that conditions the provision of citizenship to a victim of foreign repression only if the refugee takes such an oath makes a coercive proposal. Yet, Simmons argues, the validity of such an oath is an open question, one whose answer depends on whether the refugee had reasonable options other than taking the naturalization oath. A. John Simmons, Voluntarism and Political Associations, 67 VA. L. REV. 19 (1981), at 35-36. To be sure, many versions of voluntarism would dispute Simmons's logic. However, the implication of Simmons's argument is that the significance of any coercive features of the citizenship proposal can be obviated when the refugee takes the oath. Thus the ratification objection is viable on Simmons's version of voluntarism, albeit perhaps not on other versions. 
There are two aspects to the ratification objection. The first aspect is the claim that agreeing to a wrongful proposal could change the wrongfulness of the proposal. If a blackmail proposal is coercive, then (on the usurpation notion of coercion) it wrongfully impinges on the target's deliberative authority. Yet part of having this deliberative authority seems to include the power to change the status or blame-aptness of actions that would otherwise wrong one or violate one's rights. ${ }^{27}$ This exercise is consent when it occurs prior to the wrongdoing or violation and it is ratification when it occurs afterward. The second aspect is the claim that when someone attempts to impinge on an agent's deliberation, entering into an agreement regarding the subject of the attempted impingement actually does ratify that impingement. According to the ratification objection, then, the target's entering into the blackmail agreement could (and sometimes does) change the wrongfulness of the impingement in the blackmail proposal. ${ }^{28}$

27 See DAvid Owens, Shaping the Normative LANDSCAPE (2012), ch. 11.

${ }^{28}$ In correspondence, Shaw suggests a different way to deny the ratification objection from the one proposed here. Rather than disputing whether any blackmail agreement does ratify the usurpation implicit in the blackmail proposal, Shaw might deny that any agreement could change the usurpation implicit in the proposal. The argument, drawing from Pallikkathayil's notion of "impaired normative authority," is that a coercive proposal by a blackmailer necessarily invalidates the target's default discretionary authority, including his authority to enter into agreements. See Pallikkathayil, supra note 14, at 17, 19; see also David Owens, Duress, Deception, and the Validity of a Promise, 116 Mind 293 (2007), at 304-305; Ram Rivlin, Blackmail, Subjectivity and Culpability, 28 CAN. J.L. \& JURISPRUDENCE 399 (2015), at 419-421; Lamond, supra note 1, at 234.

However, this "impaired normative authority" strategy seems to get the wrong answer in a variety of blackmail scenarios. In Wilde's actual case, it would imply that Wilde could not have made a valid promise to Allen in the wake of Allen's proposal. Yet Wilde's actual transfer of a half-sovereign to Allen seems valid. If Wilde had filched the coin from Allen's purse after having handed it over, then Wilde would have been stealing. Since Wilde had the power to give a sovereign to Allen, it seems to follow that Wilde also had the power to promise to give Allen a half-sovereign. 
Consider a real-world example of the ratification objection. Under U.S. law, sexual harassment is a form of gender discrimination and therefore violates the Civil Rights Act of 1964. Many tokens of sexual harassment are coercive in exactly the way that blackmail proposals are. For example, in the prototype of quid pro quo sexual harassment, the harasser's proposal references an act that he is otherwise entitled perform (e.g., firing, demoting, or refusing to hire the target) unless the target enters an exchange whereby the harasser agrees not to act in this way and the target agrees to have sex with the harasser. The prevailing legal view in the U.S. is that only "unwanted" conduct can constitute sexual harassment. ${ }^{29}$ The U.S. Supreme Court has found that a plaintiff's actions (like participating in sexually charged banter or assenting to a sexual relationship with the harasser) can support the inference that ostensibly harassing behavior was not unwanted and thus change whether such behavior was coercive sexual harassment in the first place. ${ }^{30}$ The Court's reasoning here reflects a form of the ratification objection: in the wake of an objectionable proposal, a subordinate's acquiescence to the proposal from a superior can change whether the proposal has the significance that coercive proposals typically have.

Many scholars see the U.S. Supreme Court's focus on unwelcomeness as mistaken. Yet the ratification objection seems more broadly incorrect in contexts like sexual harassment and blackmail. In the wake of these kinds of coercive proposals (e.g., "have sex with me or you will lose your job" or "agree to pay me or I will expose your secret"), the target's mere acquiescence does not usually change whether the proposal has

${ }^{29}$ Meritor Savings Bank v. Vinson, 477 U.S. 57, 68 (1986) ("The gravamen of any sexual harassment claim is that the alleged sexual advances were 'unwelcome."').

${ }^{30} I d$. 
the significance that wrongful proposals have. Targeting someone for blackmail or sexual harassment in these ways is objectionable, even if the target accedes to the proposal.

The simple account focuses on the wrongfulness of proposals and so lacks the resources to dispute the ratification objection on these grounds. Explaining why entering into a blackmail agreement does not typically cleanse blackmail of its impermissibility requires identifying wrong-making features of certain kinds of agreements independently of the wrong-making features of proposals.

\section{The Compounding Effect}

The ratification objection is not merely mistaken but backward. Typically, in the wake of a blackmail proposal, the target's entering into a blackmail agreement amplifies rather than obviates the wrongfulness of the blackmailer's conduct. Call this the compounding effect.

A variety of theories can appreciate the compounding effect. Since the emphasis so far has been on the simple account, assume (with Shaw) that blackmail is wrongful because the proposal usurps the target's deliberative authority in a way that manifests disregard for him or her. In Wilde's actual case, Allen's blackmail proposal was rejected. Consider this variation on the case:

Wilde1: Wilde agrees to the exchange that Allen proposes. As a result of this agreement, Allen incurs an obligation not to reveal Wilde's letter to authorities and Wilde incurs an obligation to pay Allen $£ 60$.

It seems to me that Allen would commit a greater wrong in Wilde1 than he did in real life. This difference should be appreciable to any coercion-based view, and especially if the wrongfulness of coercion is appreciated in terms of "usurpation." If the 
agreement between Allen and Wilde were valid, ${ }^{31}$ then Wilde's acquiescence to the proposal would appear to change his normative situation. After entering the agreement, Allen would have a "distinctive standing, authority, or sovereignty in relation to" Wilde. ${ }^{32}$ Any subsequent effort by Wilde to avoid paying for Allen's silence would wrong Allen, since it would violate Allen's authority over Wilde. Yet this development seems perverse. In making the blackmail proposal, the blackmailer wrongfully seeks to exercise control over the target's deliberative authority. This attempted usurpation would succeed if the blackmailer were to acquire the power to change what the target is permitted or required to do going forward.

The simple account has difficulty explaining the compounding effect for the same reasons that it has difficulty resisting the ratification objection. The simple account focuses on the coerciveness of the announcement, but it does not examine whether that announcement "has some actual effect on [the target's] deliberation",33 or the power relations between the blackmailer and target. The simple account therefore could not identify a meaningful difference between the coerciveness of Allen in Wilde1 and in Wilde's actual case (where the proposal was rejected). Yet this conclusion is both counterintuitive and inconsistent with the usurpation notion of coercion. If the agreement between Wilde and Allen is valid, then Wilde1 involves a successful rather than merely attempted usurpation of Wilde's default discretionary authority. On the assumption that coercion is wrongful because it interferes with someone's discretionary authority,

\footnotetext{
${ }^{31}$ I relax this assumption infra at note 89.

32 Stephen Darwall, Demystifying Promises, in Promises AND AGREEMENTs: PHILOSOPHICAL ESSAYS 255 (Hanoch Sheinman ed., 2011), at 259.

${ }^{33}$ Shaw, supra note 1 , at 166 n. 3.
} 
actually acquiring the power to change someone's normative situation would be a greater interference (and more wrongful) than an unsuccessful attempt to acquire this power. ${ }^{34}$

A full explanation of why blackmail is wrong should therefore both resist the ratification objection and capture (or else explain away) the compounding effect. Because the simple account focuses on the wrongfulness of the blackmail proposal, it cannot easily meet either of these challenges.

\section{Criminalizing Blackmail}

A third set of challenges concerns criminalization. Most people believe that blackmail is immoral and also that it should be illegal. ${ }^{35}$ This intuition is realized in the law, since blackmail is illegal in every U.S. jurisdiction and under the laws of every Commonwealth country. Indeed, theoretical discussions of blackmail usually aim to justify these legal prohibitions, with the moral wrongfulness of blackmail typically relevant as a premise in an argument about why blackmail should be criminalized. ${ }^{36}$ Likewise, those who favor the decriminalization of blackmail often concede (at least for the sake of argument) that many tokens of blackmail are immoral but deny that this immorality is sufficient to justify legal prohibition. ${ }^{37}$

Shaw's argument for the simple account analyzes blackmail as a moral

phenomenon. Yet the simple account strongly (and perhaps uniquely) supports decriminalizing blackmail. Shaw contends that if the reasons for legally prohibiting blackmail parallel the reasons that blackmail is morally wrong, then there is a tension in

34 The compounding effect is also appreciable on alternative notions of wrongful coercion, as discussed in the appendix in connection with the "wrongful pressure" notion of coercion that undergirds Berman's evidentiary theory.

${ }^{35}$ Experimental work by Paul Robinson and colleagues supports this conjecture. Paul $\mathrm{H}$. Robinson, Michael T. Cahill \& Daniel M. Bartels, Competing Theories of Blackmail: An Empirical Research Critique of Criminal Law Theory, 89 TEX. L. REV. 291 (2011).

${ }^{36}$ E.g., Berman, Blackmail, supra note 1, at 67 and 71-73.

${ }^{37}$ See, e.g., Eric Mack, In Defense of Blackmail, 41 PHIL. STUD. 273 (1982); Walter Block, The Crime of Blackmail: A Libertarian Critique, 18 CRIM. Just. ETHICS 3 (1999), at $8-9$. 
the law. ${ }^{38}$ Blackmail proposals are illegal, and releasing truthful information about someone is legal. Yet both kinds of cases can involve infringements of the target's deliberative rights in a way that manifests an impermissible disregard for his or her interests or authority. ${ }^{39}$ To clear up this tension, Shaw argues that we should either revise what criminal law prohibits or else change how we justify this prohibition. Shaw suggests three options: decriminalize blackmail; criminalize otherwise lawful information releases when they manifest disregard for a target; or allow "nonmoral concerns" (such as free speech values or epistemic doubts about identifying the reasons for which someone acts) to justify the difference in treatment. ${ }^{40}$

Shaw does not indicate which of these options he favors, but only the decriminalization option seems viable. Any liberal account of criminalization would have difficulty justifying an arrangement in which information releases that manifested impermissible disregard were prohibited whereas otherwise identical information releases that did not manifest such disregard were decriminalized. ${ }^{41}$ Likewise, justifying blackmail's criminalization in nonmoral terms would be revisionist, since the intuition that blackmail should be legally prohibited seems intimately connected with the intuition that blackmail is morally wrong. ${ }^{42}$

${ }^{38}$ Shaw, supra note 1, at 195.

${ }^{39} I d$.

${ }^{40}$ Id. at 195-196; see also Berman, Blackmail, supra note 1, at 72-73.

${ }^{41}$ See Joel Feinberg, Some Unswept Debris from the Hart-Devlin Debate, 72 SYNTHESE 249 (1987), at 259-260.

${ }^{42}$ Saul Smilansky, May We Stop Worrying about Blackmail?, 55 ANALYSIS 116 (1995), at 120 . 
Furthermore, the simple account has difficulty responding to perhaps the most powerful abolitionist argument: that any coercion-based case for criminalizing blackmail will also call for criminalizing a variety of "hard economic transactions" that presumably should not be criminalized. ${ }^{43}$ To pull off this argument, the abolitionist postulates a licit economic transaction that involves exactly the same considerations that purportedly make blackmail wrongful — on Shaw's view, that the proposal is an attempt to usurp the target's deliberative authority and manifests impermissible disregard for him. Shaw offers the case of Fred the Landlord and Lucy the Tenant to illustrate impermissible disregard, ${ }^{44}$ and the case can be modified slightly in order to invoke the usurpation notion of coercion. ${ }^{45}$ Shaw concludes that Fred's actions towards Lucy are immoral, yet he concedes that they are within Fred's "legal rights." 46 If so, then the coerciveness of a transaction type is insufficient to justify criminalizing (proposals to engage in) that transaction type-exactly as the abolitionist contends.

Thus the simple account has a tendency toward abolitionism. To the extent that the simple account can explain why blackmail is morally wrong, it cannot explain why blackmail should be illegal or why this illegality is a function of blackmail's moral

${ }^{43}$ Jeffrie G. Murphy, Blackmail: A Preliminary Inquiry, 63 Monist 156 (1980); Russell Christopher, Meta-Blackmail, 94 GEO. L.J. 739 (2006), at 768-769.

${ }^{44}$ In Shaw's example, Fred is a landlord, and Lucy his tenant on a monthly lease. Fred has previously warned Lucy that he may terminate their arrangement on short notice, although he realizes that doing so would make things very difficult for Lucy. Shaw supposes that Fred decides to terminate the lease for the not-very-good reason that "he has grown a little tired of having Lucy in the building." Shaw, supra note 1, at 169-170. ${ }^{45}$ For example, Fred could tell Lucy, "I will kick you out unless you start looking for a new job," even though Fred could not care less about what job Lucy has.

${ }^{46}$ Shaw, supra note 1 , at 170. 
wrongfulness. Nor can it differentiate blackmail from hard (but licit) commercial transactions.

To be sure, this abolitionist tendency does not necessarily provide grounds for rejecting the simple account. Despite the ubiquity of blackmail's criminalization, abolitionism might be the correct legal position. Nor does a tendency toward abolitionism challenge the simple account on its own terms. Shaw's primary aim is to analyze blackmail as a moral phenomenon, so it is not an internal criticism of his argument that the simple account fails to resolve the legal puzzle of blackmail. However, in order to avoid abolitionism or a revisionist case for criminalizing blackmail, the simple account requires supplementation.

In summary, Shaw's simple account provides a powerful explanation of why blackmail is coercive. It also captures the inchoate nature of blackmail and dissolves two so-called paradoxes of blackmail. However, the simple account is incomplete. It cannot rule out that entering into a blackmail agreement ameliorates the objectionable aspects of the blackmail proposal, nor can it explain why a blackmailer's wrongdoing might be amplified when the target agrees to the proposal. Further, the simple account's case for why blackmail is morally wrong has either abolitionist or revisionist implications regarding the criminalization of blackmail.

The difficulties facing Shaw's simple account generalize to other coercion-based account of blackmail. ${ }^{47}$ Like many other theories (and nearly every other coercion-based

\footnotetext{
${ }^{47}$ Space constraints prevent a full defense of this claim. However, I demonstrate in the appendix why the difficulties facing the simple account also apply to Berman's evidentiary theory (which utilizes a different notion of coercion).
} 
account), ${ }^{48}$ the simple account explains the wrongfulness of blackmail in terms of the blackmail proposal. Yet, if the arguments in this Subsection are sound, then addressing the ratification objection and the compounding effect requires analyzing the blackmail agreement as well as the blackmail proposal. Furthermore, any coercion-based view faces significant (and, according to some, insurmountable) difficulty in explaining why blackmail is appropriately criminalized whereas other kinds of transactions that involve the same degree of coercion are licit. ${ }^{49}$

\section{WHY BLACKMAIL IS WRONG: A COMPLEX ACCOUNT}

It is possible to preserve the strengths of a coercion-based view like the simple account while avoiding these difficulties. The simple account and other coercion-based views largely focus on the wrong-making features of the blackmail proposal and neglect the wrong-making features of the blackmail agreement. The following view remedies this shortcoming:

Complex Account: Blackmail is wrong because (i) the blackmail proposal is coercive; and/or (ii) the blackmail agreement contemplated in the proposal is fraudulent.

The explanation for (i) can vary based on the coercion-based account that one favors. Shaw's simple account makes the case for (i) in terms of the "usurpation" notion of wrongful coercion, whereas other coercion-based accounts utilize different notions of wrongful coercion. I mean this formulation to be compatible with the simple account and any other coercion-based view. Defending the complex account also requires establishing

${ }^{48}$ See, e.g., Berman, Blackmail, supra note 1, at 72; Clark, supra note 24, at 59-60; Fitzpatrick, supra note 1, at 45; Gorr, supra note 1, at 44; Lamond, supra note 1, at 223225.

${ }^{49}$ See, e.g., Christopher, Meta-Blackmail, supra note 43, at 769; Henry E. Smith, Harm in Blackmail, 92 Nw. U. L. REV. 861 (1998), at 889. 
that (ii) is true. I undertake this task in Subsection A. A full defense also requires showing that the case for (i) is compatible with the case (ii), that the complex account can both replicate the success of coercion-based views and improve on their shortcomings. Subsection B addresses these issues within the ambit of Shaw's simple account.

\section{A. Why Blackmail Agreements Are Fraudulent: Two Arguments}

Fraud is a complicated wrong and crime. The judgment that behavior is fraudulent depends crucially on context. Actions that are fraudulent in some circumstances are not necessarily fraudulent in others. ${ }^{50}$ Consider this intuitively plausible claim.

Valueless Fraud: It is fraudulent to attempt to exchange a token that you know

(or have good reason to know) lacks the value characteristic of the type of which that token is an instance.

Valueless fraud implies that a core aspect (although, perhaps, not the whole) of fraud is value. Proving criminal law charges of fraud usually requires showing that the defendant has deceived the target, ${ }^{51}$ but deception matters mainly in virtue of its connection to value. Say that Ben is a customer and Theresa is a shopkeeper. Ben pays for goods with a check whose drawee is a bank that Ben does not have an account with. Checks have value qua checks because they convey valid claims on a drawee. Ben's hot check lacks the value characteristic of checks for Theresa because Ben has no claims to convey. In handing the check over to Theresa, Ben implicitly misrepresents that his check

${ }^{50}$ See Samuel Buell, Novel Criminal Fraud, 81 N.Y.U. L. REv. 1971 (2006), at 19731975.

${ }^{51}$ See, e.g., Stuart P. Green, Lying, Cheating, ANd Stealing: A Moral Theory of White-COLlar CRIME (2006), at 153-160. 
has the value that checks characteristically have. Ben's check lacks this value, and Ben has good reason to know this. Therefore Ben is guilty of check fraud. ${ }^{52}$

Valueless fraud can also arise in the context of agreements. Here the relevant value must be mutual-you defraud someone if you enter into an agreement that you know (or should know) would lack value for her, even if that agreement would have value for you. Thus it would be fraud for Bob to enter into an agreement with Tammy if he has good reason to know, at the time of formation, that the agreement lacks value for Tammy. By proposing that he and Tammy enter into such an agreement, Bob would attempt to defraud Tammy. This insight grounds the tort of "promissory fraud": because every promise "necessarily carries with it the implied assertion of an intention to perform," a promise "made without such an intention is fraudulent and actionable in deceit." 53

Promissory fraud presupposes that agreements are valuable in part because they create certain obligations and manifest certain commitments. Hanoch Sheinman calls this insight the "face value principle for agreements" - the notion that valuable agreements

${ }^{52}$ For example, the Model Penal Code defines check fraud as the issuing or passing a check for the payment of money that one knows will not be honored by the drawee. If the issuer has no account with the drawee at the time the check is issued, then there is a presumption that that issuer knows that the check will not be paid. MODEL PENAL CODE $\S 224.5$ (1985).

${ }^{53}$ RESTATEMENT (SECOND) OF TORTS, $\$ 530 \mathrm{cmt}$ c (1977); RESTATEMENT (SECOND) OF CONTRACTS $\S 171 \mathrm{cmt}$. b (1981). Some deny that obligations and commitments necessarily run together in agreements. These theorists contend that agreements in which only obligations are exchanged can be (and are) valuable in a many circumstances, including when performing is roughly equivalent to paying damages. See IAN AYRES \& GREGORY KLASS, InsincERE PROMISES: THE LAW OF MisRePRESENTED INTENT (2005), at 93-095. However, even if commitment-less agreements might be valuable in some circumstances, these circumstances are not applicable to blackmail agreements for the reasons discussed below. 
characteristically involve both obligations and "relational commitments to do one's part of the deal., ${ }^{, 54}$ If Bob and Tammy enter into an agreement that Bob (at the time of formation) has no intention to perform, then their agreement lacks the prima facie value that agreements have. Because their agreement lacks value, Bob defrauds Tammy regardless of whether his subsequent behavior happens to conform to the terms of the agreement. $^{55}$

If valueless fraud is true, then whether a blackmail agreement is fraudulent depends on whether it lacks value qua agreement. Recall the preliminary definition offered above that the blackmail agreement is the undertaking, in response to the blackmail proposal, through which target agrees and thereby becomes obligated to do $\mathrm{Y}$ (e.g., pay money to the blackmailer), the blackmailer agrees and thereby becomes obligated not to do X (e.g., disclose the information), and these obligations interdepend in the way that is constitutive of agreements. We can now see that this definition is incomplete. For example, Sheinman's “face value principle of agreements" suggests that the blackmailer's intentions at the time of formation can determine whether the agreement has value. ${ }^{56}$ If the blackmailer intends to disclose the target's information, then the agreement would lack value for the target. The target would be in a worse situation after making the agreement than she was before — not only would her secret be liable to

\footnotetext{
${ }^{54}$ Sheinman, supra note 7 , at 367.

${ }^{55}$ Ian Ayres \& Gregory Klass, Promissory Fraud without Breach, WIS. L. REV. 507 (2004), at 511-514.

${ }^{56}$ Ayres and Klass allow that mutually valuable agreements need not always be accompanied by intentions to perform one's obligations, but note that agreements based on "blank promises" (in which one party intends at the time of agreement not to act in the way that the she promises) lack mutual value. AYRES \& KLASS, INSINCERE PROMISES, supra note 53, at 96-97.
} 
exposure, but (assuming the agreement is valid) she would lack authority to decide whether to give money to the blackmailer.

In addition to obligations and commitments regarding nondisclosure, a valuable blackmail agreement also generates obligations and corresponding commitments regarding unilateral renegotiation. George Fletcher contends that blackmail agreements threaten to instantiate a "relationship of dominance and subordination" between the blackmailer and the target, the essence of which "is the prospect of [the blackmailer's] repeated demands." ${ }^{57}$ These repeated demands are a way of unilaterally renegotiating the terms of the agreement. Seen in this light, blackmail agreements present a daunting first performer problem. The target's action (paying the money) happens at the outset of the exchange, whereas the blackmailer's action (keeping the secret) is distributed over time. After the target has initially performed, the blackmailer might unilaterally raise the cost of silence beyond the price contemplated in the agreement. As Ronald Coase puts it: business negotiations (which may also cause anxiety) either lead to a breakdown of the negotiations or they lead to a contract. There is, at any rate, an end. But in the ordinary blackmail case there is no end. The victim, once he succumbs to the blackmailer, remains in his grip for an indefinite period. ${ }^{58}$

\footnotetext{
${ }^{57}$ George Fletcher, Blackmail: The Paradigmatic Crime, 141 U. PA. L. REV. 1617 (1993), at $1626-1627$.

${ }^{58}$ Ronald Coase, Blackmail, 74 VA. L. REV. 655, 675 (1988); Murphy, supra note 43, at 166. Ironically, the more rational the target is in appreciating the irrelevance of sunk costs, the more vulnerable he is to this form of predation. See Steven Shavell, $A n$ Economic Analysis of Threats and Their Illegality: Blackmail, Extortion, and Robbery, 141 U. PA. L. REV. 1877 (1993), at 1885-1886.
} 
Thus a valuable blackmail agreement must also generate obligations for the blackmailer regarding unilateral renegotiation as well as commitments that correspond to these obligations.

To illustrate this point, consider another variation on Wilde's case:

Wilde2: In response to Allen's proposal, Allen and Wilde enter into an agreement under which Allen is obligated not to turn over the letter to authorities and Wilde is obligated to pay Allen $£ 60$. However, Allen intends not to abide by the agreement and to come back to Wilde for more funds after spending the initial $£ 60$.

Allen would seemingly commit a greater wrong in Wilde2 than in Wilde1 (and, by extension, greater than Allen committed in real life). In Wilde1, Allen may or may not be committed to keeping his part of the agreement. In Wilde2, Allen would be committed to breaking the agreement at the time of formation. Therefore, the agreement in Wilde 2 would lack value in at least one way that the agreement in Wilde1 does not necessarily lack value. $^{59}$

Explaining the extent of the transgression in Wilde2 requires updating the definition of valuable blackmail agreements. In order for the blackmail agreement to be valuable for the target, the blackmailer must, at the time of formation, incur an obligation not to do $\mathrm{X}$ and an obligation not to renegotiate the terms of the agreement unilaterally, and he must have commitments that correspond to these obligations. The point is not merely that the savvy target would bargain for these obligations and commitments.

${ }^{59}$ Because, as discussed below, Allen acts coercively and commits fraud in both Wilde1 and Wilde2, the difference in wrongfulness between these cases is only one of degree. 
Rather, if any of these obligations or commitments were not present, then the blackmail agreement would lack value for the target (and therefore lack the mutual value that agreements characteristically have).

Yet even this revised list of obligations and commitments does not fully capture the constituents of a valuable agreement. These obligations and commitments could be generated in other ways, for example through a series of representations that engender reliance or through disconnected promises between the blackmailer and the target. Consider the difference between promises and predictions of future behavior or intentions. If Allen were to promise Wilde that he would not disclose Wilde's secret, then Allen would enable Wilde to hold him accountable for keeping the secret in different ways than if Allen merely predicted that he would not disclose the secret to anyone in the future. ${ }^{60}$ Promises come preequipped with accountability mechanisms that predictions of future behavior do not necessarily have.

Likewise, agreements have special accountability mechanisms that promises do not necessarily have. ${ }^{61}$ If Wilde and Allen reach an agreement whereby Allen is to keep Wilde's secret and Wilde is to pay Allen money, then Wilde can hold Allen accountable for keeping the secret in ways that would not necessarily be possible if these same obligations had arisen through a series of disconnected promises. For example, agreements allow a party to hold his counterparty accountable prior to the counterparty's

${ }^{60}$ David Owens, A Simple Theory of Promising, 115 PHIL. REV. 51 (2006), at 54-61.

${ }^{61}$ E.g., DARWALL, SECOND-PERSON, supra note 14, at 198-199; Sheinman, supra note 7, at 368. These mutual accountability mechanisms are generic features of agreements. Although these mechanisms can be fashioned out of disconnected promises, they are not generic to promises in the way that they are to agreements. Id. at 378-379 and 383-385. 
violating her obligations. ${ }^{62}$ By contrast, conditional promises do not necessarily allow for this kind of prebreach accountability. Furthermore, agreements also have postbreach accountability mechanisms that are not always available for promises. ${ }^{63}$ In order for the blackmail agreement to have mutual value, both parties must have access to these accountability mechanisms, regardless of whether either party utilizes them or has need to.

To summarize, a valuable blackmail agreement requires not only that the blackmailer has obligations and corresponding commitments regarding nondisclosure and unilateral renegotiation but also that the target has access to the special forms of mutual accountability that characterize agreements. If an agreement that lacks any of these components is fraudulent, then there are two separate arguments for why blackmail agreements are wrong.

\section{The Contingent Argument}

Appreciating one such argument requires two further assumptions. The first is an empirical claim that many blackmailers lack the commitments regarding nondisclosure and avoiding unilateral renegotiation that are required to make a blackmail agreement mutually valuable. The second is a nostrum about criminalization: if many tokens of a certain type of activity are morally problematic and justify criminalization, then the state may legitimately criminalize that type of activity. ${ }^{64}$

Given these assumptions, what follows is a contingent argument about why

blackmail is wrongful and appropriately criminalized:

${ }^{62}$ Legal examples of these accountability mechanisms include injunctive and declaratory relief and the doctrine of anticipatory repudiation.

${ }^{63}$ The most notable example here is the panoply of legal remedies that are available for breaches of contract but not for promises.

${ }^{64}$ See, e.g., Mitchell Berman, Meta-Blackmail and the Evidentiary Theory: Still Taking Motives Seriously, 94 GEO. L.J. 787, 795 (2006); JOHN GARDNER \& Stephen Shute, The

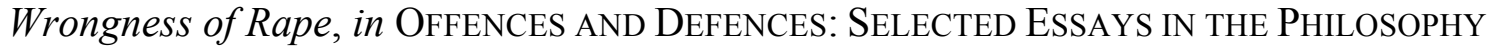
OF CRIMINAL LAW 1 (2007), at 29-32. 
(1) In any mutually valuable blackmail agreement, both parties have obligations and commitments regarding nondisclosure and renegotiation, as well as access to the mutual accountability mechanisms that are characteristic of agreements.

(2) Many blackmailers lack the commitments described in (1).

(3) When the conditions of (2) are realized, a blackmail agreement lacks value for the target.

(4) It is fraudulent to exchange a token that you know (or have good reason to know) lacks the value characteristic of the type of which that token is an instance.

(5) When the conditions of (2) are realized, a blackmail agreement is fraudulent.

(6) If many tokens of a certain type of activity are fraudulent and fraudulence is a sufficient basis for criminalization, then the state may legitimately criminalize that type of activity.

(7) The state may legitimately criminalize blackmail agreements.

(8) Because the state may criminalize blackmail agreements, it may also criminalize proposals to enter into such agreements.

Premise (1) is the definition of valuable blackmail described above; (2) is the empirical assumption; (3) follows from (1) and (2). (4) is the valueless-fraud proposition; (5) follows from the combination of (3) and (4); (6) is the application of the nostrum about criminalization, described above, to fraud; (7) follows from (5) and (6); (8) is the combination of (7) and what Mitchell Berman calls the "threat principle," which says that 
the legal and moral permissibility of a conditional proposal "tracks the permissibility" of the conduct conditionally proposed. ${ }^{65}$

This contingent argument can explain why the ratification objection does not apply in cases like Wilde2. Allen's proposal is, among other things, an attempt to usurp Wilde's deliberative authority. Even if some valid agreement could ratify this incursion, any agreement emanating from Allen's proposal would not have this effect. Such an agreement would lack mutual value because Allen would be committed to violating it. By entering into an agreement that lacks value for Wilde, Allen would commit a greater moral transgression than the real-life Allen did. He would not only attempt to usurp Wilde's deliberative rights but also use him as a money pump. It is independently wrong to use someone in this way. Therefore, the contingent argument also explains the compounding effect of the blackmail agreement in Wilde2.

The contingent argument also provides a straightforward justification for criminalizing blackmail—namely, because many blackmail agreements are fraudulent. Almost everyone, including libertarians who call for blackmail's decriminalization, accepts that efforts to defraud may be criminally prohibited. ${ }^{66}$ Therefore the contingent argument provides a reason for criminalizing blackmail that even an abolitionist could accept.

${ }^{65}$ Berman, Blackmail, supra note 1, at 42; see also Shaw, supra note 1, at 168.

${ }^{66}$ See Walter Block, Berman on Blackmail: Taking Motives Fervently, 3 FLA. ST. U. BuS. REV. 57 (2003), at 69-71, 107; Richard A. Epstein, Blackmail, Inc., 50 U. CHI. L. REV. 553 (1983). 
A critic might challenge the contingent argument in several ways. One criticism denies the empirical premise. Historical evidence supports this premise, ${ }^{67}$ and gametheoretical analysis suggests that the behavioral patterns described in the empirical premise would be rational. ${ }^{68}$ Moreover, the empirical premise has historical resonance. Consider Sherlock Holmes's description of Charles August Milverton, the fictional "king of all blackmailers": "Heaven help the man, and still more the woman, whose secret and reputation come into the power of Milverton! With a smiling face and a heart of marble, he will squeeze and squeeze until he has drained them dry." ${ }^{69}$ Holmes's metaphor of a blackmailer squeezing his target dry suggests that the empirical premise resonated in the Victorian era no less than ours. However, given the secrecy with which most blackmail is conducted, it is difficult to verify the empirical premise.

Second, a critic might deny the nostrum about criminalization. Perhaps the nostrum is overly broad, since it allows for criminalization of entire types of behaviors when some tokens do not themselves run afoul of legal prohibitions. However, if a type of behavior is on balance morally problematic, then seemingly any plausible theory of criminalization could justify the legal prohibition of this type, even if some tokens of the behavior are themselves harmless. ${ }^{70}$

${ }^{67}$ E.g., McLaren, supra note 2; Mike HePworth, BlackMail: Publicity AND SECRECY IN EVERYDAY LIFE 42 (1975).

${ }^{68}$ Shavell, supra note 58, at 1885-1887.

${ }^{69}$ A.C. Doyle, "The Adventure of Charles Augustus Milverton,” in The COMPLETE SHERLOCK HOLMES 572-573 (1960) (emphasis added).

${ }^{70}$ See, e.g., Douglas Husak, Overcriminalization: The Limits of THE CRIMINAL LAW (2008), at 159-176; R.A. Duff \& Sandra Marshall, Remote Harms and the Two Harm Principles, in LiBERAL CRIMINAL THEORY: ESSAYS FOR ANDREAS VON HIRSCH 205 (A.P. Simester, Ulfrid Neumann \& Antje du Bois-Pedain eds., 2014), at 207. To alleviate 
Third, the critic might assert that the commitment-less blackmail agreement actually has value for the target. This objection would challenge the definition of mutually valuable blackmail agreements by denying that a counterparty's commitment to act in the way that an agreement contemplates is necessary for the agreement be valuable. Perhaps commitment-less blackmail agreements would have value in providing the blackmailer with a pro tanto reason not to disclose or renegotiate or in providing the target with some hope that the blackmailer will not act in these ways. Yet these kinds of value are nonstandard. On the same logic, certain hot checks might have value. For example, a hot check written by Bill Gates would have kitsch value, given Gates's enormous wealth. Indeed, a hot check by Bill Gates written for, say, $\$ 2$ would arguably have more value as a collectable than a viable check written by him for the same amount. However, Bill Gates's \$2 hot check would still be fraudulent because it would lack the value that is characteristic of checks. Likewise, an agreement would lack the characteristic value of agreements if one of the parties were, at the time of formation, committed not to act in the way that the agreement requires. ${ }^{71}$ Thus a commitment-less blackmail agreement would run afoul of the valueless-fraud principle even if it also had some nonstandard value.

Fourth, the critic might argue that the contingent argument is incomplete. The contingent argument derives a conclusion about fraud from premises concerning value.

legality concerns related to overbreadth, a state might legitimately criminalize a type of behavior that tends to be objectionable and provide an affirmative defense against liability for those who perform unobjectionable tokens of that behavior. Thanks to Grant Lamond for suggesting this point.

${ }^{71}$ See RESTATEMENT (SECOND) OF TORTS, $\$ 530 \mathrm{cmt}$. c; Sheinman, supra note 7, at 367; Ayres \& KLASS, InsinCERE PROMISES, supra note 53, at 96-97. 
However, the critic might contend, showing that an agreement lacks value for the target qua agreement does not establish that the blackmailer has committed fraud. Proving fraud also requires showing some misrepresentation by the blackmailer and (perhaps) that the target reasonably relied on this misrepresentation. Yet, the critic might conjecture, many blackmailers do not misrepresent their commitments. On this criticism, then, a blackmailer would not commit fraud if he were to represent accurately his lack of commitment to nondisclosure and avoiding renegotiation or if the target did not actually believe that the blackmailer was committed to living up to his obligations.

This incompleteness objection does not apply to fraud in the context of agreements. By entering into an agreement, each party makes several implicit representations. One set of representations concerns commitments to acting in the way that the agreement specifies. Another implicit representation is that, to the best of his or her knowledge, the agreement could have the mutual value that agreements characteristically have. No explicit representation is required to establish that such an agreement is fraudulent. Rather, these representations can be inferred from the creation of the agreement. In the hot-check scenario described above, Ben could not escape liability by arguing that he never told Theresa that he had an account at the bank indicated on the check. Likewise, under the doctrine of promissory fraud, a blackmailer could not escape liability by contending that he did not represent that he would fulfill his part of the bargain at the time of formation. The existence of such a representation (as well as the 
target's belief that the blackmailer was so committed) can be presumed from the formation of the agreement. ${ }^{72}$

A more pressing objection is that although the contingent argument might justify why blackmail can be criminalized, it fails to establish that blackmail agreements are morally wrong in a variety of circumstances. Consider the following variation on Wilde's case.

Wilde3: Allen proposes the agreement to Wilde just as in real life. Should Wilde enter the agreement, Allen would be sincerely committed to keeping Wilde's letter secret and to avoiding renegotiation of the terms. Rather than being affronted by Allen's proposal, Wilde is grateful and feels no pressure to accept. He would gladly pay far more than $£ 60$ for Allen’s silence. Therefore, Wilde enthusiastically accepts Allen's proposal and enters into the agreement.

Because Allen is committed to living up to his part of the agreement in Wilde3, his behavior falls outside the contingencies of the contingent argument. Also, Allen's behavior is arguably not wrongfully coercive, ${ }^{73}$ even under the "usurpation" notion that undergirds the simple account. ${ }^{74}$ Deliberative authority (like other normative powers) can

\footnotetext{
${ }^{72}$ Further, although the target's reliance is typically an element of the common-law tort of fraud, reliance is not an essential element of criminal prohibitions of fraud or in statutory schemes that punish fraud (such as consumer protection statutes or securities law). John C.P. Goldberg, Anthony J. Sebok \& Benjamin C. Zipursky, The Place of Reliance in Fraud, 48 ARIZ. L. REV. 1001 (2006).

${ }^{73}$ For example, on Fitzpatrick and Lamond's views, the proposal in Wilde3 would not be coercive because Wilde welcomes it. Fitzpatrick, supra note 1, at 39; Lamond, supra note 1 , at 226. On Berman's view, the proposal would (probably) not be coercive because it does not exert pressure on Wilde. Berman, Blackmail, supra note 1, at 66.

74 On Shaw's logic, even if Allen's proposal in Wilde3 were an attempt to usurp Wilde's deliberative authority, it might not be wrongfully coercive if it did not manifest impermissible disregard concerning Wilde. Shaw, supra note 1, at 179.
} 
be ceded, and Allen's proposal attempts to take control over deliberative rights that Wilde happily relinquishes. Moreover, even if Allen's proposal were wrongfully coercive, the agreement between Allen and Wilde would seem to ameliorate these objectionable features, just as the ratification objection predicts. Finally, Allen's conduct in Wilde3 does not seem obviously worse than his conduct in real life. Wilde 3 thus appears to defy the compounding effect. In sum, if the contingent argument is the only basis for establishing that blackmail is fraudulent, then it is difficult to conclude that Allen's conduct in Wilde 3 is wrongful.

The contingent argument, then, provides a firm basis for criminalizing blackmail, but it fails to address other difficulties that beset the simple account. It cannot fully refute the ratification objection in cases like Wilde3, nor can it explain why the compounding effect is realized in these cases. More broadly, a complex account built solely on the contingent argument could not establish that blackmail is wrong in cases where the blackmail proposal is welcomed and leads to an agreement that appears to benefit the target. These shortcomings suggest two options: either concede that blackmail is not necessarily morally wrong in itself, or else find some other morally wrongful feature of blackmail agreements that is realized in cases like Wilde3.

\section{The Categorical Argument}

Blackmail is fraudulent and morally wrong because blackmail agreements lack the mechanisms for mutual accountability that characterize valuable agreements. The target cannot both hold the blackmailer accountable for his obligations and preserve the value of the agreement. Therefore, every blackmail agreement lacks mutual value and is fraudulent. $^{75}$

${ }^{75}$ David Owens also concludes that the blackmail agreement necessarily lacks value for the target, although he identifies different features to explain this lack of value. David Owens, Should Blackmail Be Banned?, 63 PHILOSOPHY 501 (1988). 
The crucial claim here is that blackmail agreements lack the accountability mechanisms that give agreements their distinctive value. ${ }^{76}$ Many of these accountability mechanisms operate by implicating nonparties to an agreement. The most obvious way that third parties are implicated is through legal institutions that enforce agreements and provide remedies for breaches. ${ }^{77}$ Blackmail agreements are not legally enforceable, so they lack these special accountability mechanisms. Suppose that after formation of the agreement a blackmailer proposes to reveal the secret to a third party or decides unilaterally to raise the price of his silence. Revealing the secret would violate the blackmailer's obligations regarding disclosure, and coming back for more money would violate his obligations regarding unilateral renegotiation. Yet the target would have no way of holding the blackmailer to these obligations or obtaining redress for their violation. The blackmailer's nonaccountability to the target indicates that the agreement lacks mutual value. This lack of value is problematic regardless of whether the blackmailer actually behaves in accordance with his obligations or whether the target ever has occasion to hold the blackmailer accountable.

The problem here is a problem of power. Agreements are supposed to give parties special powers over each other. These special powers differentiate agreements from other methods of generating obligations, like predictions of future behaviors. Regardless of whether special powers of accountability are exercised, having them is part of what makes agreements valuable. Because blackmail agreements are unenforceable, they do

${ }^{76}$ DARWALL, SECOND-PERSON, supra note 14, at 196.

${ }^{77}$ Less formally, valuable agreements implicate third parties by generating agreementbased reasons for the parties. These agreement-based reasons can be seen as "by nature public," in that their "normative force" necessarily "extends across different agents." See R. Jay Wallace, The Publicity of Reasons, 23 PHIL. PERSP. 471 (2009). 
not effectuate the power transfers that make agreements valuable. As Sidney DeLong puts it, the target "buys nothing certain with his payment because the blackmailer can renege on her promise of silence and demand more money.",78

To illustrate this analysis, consider the Wilde3 scenario discussed above. In order for an agreement with Allen to be valuable for Wilde in these circumstances, it would not be enough for Allen to have the requisite dispositions at the time of formation. Dispositions to live up to one's obligations are fickle. Nor would it be enough for Allen simply to refrain from disclosing Wilde's secret or raising the price of his silence. Allen might have behaved in exactly these ways in the absence of an agreement (as Allen did in real life). Rather, the Wilde-Allen agreement would only be valuable qua agreement if Wilde could hold Allen to his end of the deal. Yet if their blackmail agreement could not be enforced, then Wilde would lack this authority. Therefore the agreement described in Wilde 3 would lack value for Wilde because he would have no way to hold Allen accountable.

The abolitionist critic might object that this analysis begs the question. The fraudulence of blackmail agreements is, at least in part, a function of their legal unenforceability. Yet some abolitionists support not only decriminalizing blackmail but also making blackmail agreements legally enforceable. ${ }^{79}$ This type of abolitionist could argue that legally enforceable blackmail agreements would give rise to mutual accountability mechanisms. If so, then blackmail agreements are not necessarily

\footnotetext{
${ }^{78}$ DeLong, supra note 25, at 1691.

${ }^{79}$ See, e.g., Block, Crime of Blackmail, supra note 37.
} 
valueless. Rather, their lack of value is a contingent feature of our legal landscape, one that the abolitionist urges us to reform.

Answering this objection from the abolitionist requires showing that even if blackmail agreements could be legally enforced, targets would still lack the power to hold blackmailers accountable. Yet this proposition rings true. Holding a blackmailer to his obligations under a blackmail agreement would destroy the value of the agreement for the target.

To see why, recall that one set of mechanisms unique to agreements involves mutual accountability. Agreements automatically enable one party to hold the other party responsible prior to violating the agreement, whereas alternative ways of generating obligations (such as promises or predictions of future intention) do not necessarily enable such prebreach accountability. Suppose that blackmail agreements were legally enforceable and that a blackmailer violated his obligations by attempting to raise the price of his silence. For the target, enforcing this obligation against the blackmailer would require publicizing the blackmail agreement. The target would need to reveal the terms of the agreement to third parties in order to establish that the blackmailer has violated them. Yet in paradigmatic cases of informational blackmail (at least), ${ }^{80}$ the value of the blackmail agreement for the target is a function of the capacity to avoid publicizing the subject matter of the agreement. If the target's secret were made public, then the agreement would lack value for him. In such circumstances, the target "cannot complain or seek help for his dilemma without abandoning that which he wants to preserve." ${ }^{81}$ So

${ }^{80}$ Thanks to Alex Sarch for urging clarification of this point.

${ }^{81}$ DeLong, supra note 25, at 1690. 
even if blackmail agreements were formally enforceable, they would be practically unenforceable. Here, too, Sherlock Holmes's description of the blackmailer Milverton seems apt:

"But surely," said [Watson], "the fellow [Milverton] must be within the grasp of the law?"

“Technically, no doubt, but practically not. What would it profit a woman, for example, to get him a few month's imprisonment if her own ruin must immediately follow? His victims dare not hit back." 82

If the blackmailer were to attempt renegotiation of the agreement, then the target (like Milverton's victim) would "dare not hit back." Yet the power to "hit back" at one's counterparty — that is, to hold him to his end of the bargain, to avoid being squeezed until one has been drained dry-is at the heart of what makes an agreement valuable.

This analysis supports the following argument. Unenforceable blackmail agreements would formally lack value for the target, who could not hold the blackmailer accountable. Enforceable blackmail agreements would practically lack value for the target (at least of informational blackmail), who could not both hold the blackmailer accountable and preserve the value of the agreement. To elaborate:

(9) Unenforceable agreements lack mechanisms for mutual accountability.

(10) Blackmail agreements are not enforceable.

(11) Unenforceable blackmail agreements lack value for the target.

(12) Unenforceable blackmail agreements are fraudulent.

${ }^{82}$ DoYLE, supra note 69, at 573 (emphasis added). 
(13) Enforcing an agreement requires accommodation by others, or publicity.

(14) Enforcing a blackmail agreement would require publicity.

(15) In cases of informational blackmail, publicizing a blackmail agreement would destroy its value for the target.

(16) Enforceable blackmail agreements would lack value for the target.

(17) Enforceable blackmail agreements would be fraudulent.

Within this argument, (11) is the conjunction of (9), (10), and the definition of valuable agreements offered in premise (1); (12) follows from the notion of valueless fraud (represented above in premise (4)) and (11); similarly, (16) follows from (14), (15), and (1), and (17) follows from (4) and (16).

This categorical argument explains what is wrong in Wilde3. The agreement between Allen and Wilde lacks the value for Wilde that agreements characteristically have. Wilde cannot hold Allen accountable for living up to his obligations under the deal, because blackmail agreements are legally unenforceable. Moreover, even if blackmail agreements were legally enforceable, any form of holding Allen to account would require revealing the terms of the agreement to a wider audience. This publicity would destroy the value of the agreement for Wilde. Therefore the agreement in Wilde3 is fraudulent regardless of whether blackmail agreements are legally enforceable. This logic is captured in Sherlock Holmes's comment that blackmail is among the crimes "that the law cannot touch." 83

The abolitionist critic might contend that this refined version of the categorical argument is still not categorical. Just as the unenforceability of blackmail agreements is a

${ }^{83}$ Id. at 581 . 
local contingent of our legal system, so is the notion that enforcing an agreement requires the kind of publicity that would destroy the value of a blackmail agreement for the target. For example, enforcement would not require publicity if there were special, secret courts for enforcing blackmail agreements against blackmailers. Blackmail agreements might also be enforced in secret proceedings of nonspecialized courts, in the way that many contracts concerning trade secrets or confidentiality agreements are enforced. ${ }^{84}$ If such arrangements were part of our legal system, then blackmail agreements might have mutual value. Therefore, the objection goes, blackmail agreements lack mutual value only because our legal system lacks these features.

The best response to this abolitionist objection is to concede that the categorical argument is not strictly categorical. If legal arrangements allowed for the enforcement of blackmail agreements without publicity for (or scrutiny of) the subject matter, then blackmail agreements might have value for the target. However, no just legal system would include these arrangements, and the complex account can explain why. Blackmail agreements arise out of blackmail proposals, most of which (according to the simple account and other coercion-based views) are morally objectionable because of the way that they treat targets. Establishing institutions for enforcing blackmail agreements would require the state to put its imprimatur on these coercive arrangements. As Seana Valentine Shiffrin contends, states may decline to enforce morally objectionable agreements out of a "concern not to facilitate or assist harmful, exploitative, or immoral

${ }^{84}$ See, e.g., Block, Crime of Blackmail, supra note 37, at 26. 
action." In such cases, "the state refuses, for its own stake, to be a codependent." 85 A state would commit a transgression far worse than codependency or facilitation if it established special legal institutions to allow the making and keeping of blackmail agreements. Doing so would make the state an instrument of this domination, which would in turn violate the state's "deontological commitment not to assist grossly unfair treatment of one of its citizens by another." 86

To summarize the categorical argument, then, blackmail agreements are fraudulent in any just state because they lack the hallmarks of valuable agreements (especially legal and practical enforceability), and a state would act unjustly by providing mechanisms that would make such agreements mutually valuable.

\section{B. Some Strengths of the Complex Account}

This Subsection defends the coherence of the complex account, examines some of its strengths, and responds to some potential objections.

The components of the complex account fit together, as can be demonstrated by focusing on Shaw's simple account. Both coercion and fraud can infringe a target's default discretionary authority in a way that manifests impermissible disregard for him or her. Beyond this, fraud is highly correlated with coercion. Blackmail agreements are fraudulent because the target cannot hold the blackmailer accountable for living up to his or her end of the bargain. In many blackmail scenarios, this lack of formal and informal accountability is combined with a severe asymmetry regarding vulnerability. The typical target has more to lose from the blackmailer's failing to live up to his or her end of the

${ }^{85}$ Seana Valentine Shiffrin, Paternalism, Unconscionability Doctrine, and Accommodation, 29 PHIL. \& PUB. AfF. 205 (2000), at 224.

${ }^{86} I d$. at 235 . 
bargain than vice versa. These circumstances (along with the severe first-performer problem posed by blackmail agreements) provide ideal conditions for coercion to flourish. Therefore the contingent and categorical arguments about why blackmail agreements are fraudulent address the same worry about the usurpation of deliberative authority that animates Shaw's simple account.

The complex account also replicates the main strengths of Shaw's simple account. By incorporating the simple account, the complex account can explain not only why blackmail is wrong but also why it wrongs the target in particular. Many blackmail proposals are impermissible attempts to usurp the target's deliberative authority that manifest disregard for him or her. On Shaw's view, these attempts wrong the target by encroaching his or her deliberative authority. However, a blackmail proposal that is not coercive (for example, the one described in Wilde3) would still violate the target's deliberative authority, albeit indirectly through fraud. Proposing that the target enter an agreement that lacks the value characteristic of agreements is a way of tricking someone into relinquishing his full range of control over the obligations that apply to him or her. Here, the two prongs of the complex account allow for an explanation by subsumption: blackmail wrongs the target by attempting to take control over decisions that are within the target's deliberative authority, or by attempting to trick him into relinquishing that authority, or by doing both. ${ }^{87}$

${ }^{87}$ This subsumption strategy is largely an artifact of the notion of coercion utilized in Shaw's simple account. On the "usurpation" notion of coercion, fraud and coercion are not distinctive types of wrongs so much as different ways of instantiating the same wrong of impinging someone's default deliberative authority. Coercion-based accounts that utilize alternative notions of wrongful coercion (such as Berman's) do not allow for this strategy of explanation by subsumption. On such approaches, the coerciveness and 
The complex account can overcome the difficulties (described in Section I.B) that beset the simple account and other coercion-based views. First, the complex account can explain why the ratification objection is incorrect. Recall that according to some commentators, it is possible for an offeree to ratify the objectionable features of a proposal or agreement. ${ }^{88}$ The complex account identifies two potentially objectionable features typical in blackmail: the proposal is coercive, and the agreement contemplated in the proposal is fraudulent. It is not enough to contend (as with the legal definition of unwelcomeness in sexual-harassment doctrine) that the target's entering the blackmail agreement automatically ratifies the coerciveness of the proposal. In order for the ratification objection to succeed, the target must also ratify the fraudulence of the blackmail agreement. Whether this type of ratification is logically possible seems an open question. In any event, it cannot be inferred solely from the target's acceding to the proposal.

Second, the complex account can explain why entering into a blackmail agreement compounds the wrongfulness of the blackmail proposal. The real-world Allen only attempted to coerce and defraud Wilde. If Wilde had entered into a valid agreement with Allen, then this usurpation would have succeeded. By entering into such an agreement, Allen would have obtained mastery over Wilde in the form of having a claim to hold Wilde to particular obligations. The appearance of this mastery to Wilde is objectionable itself, even if (due to the coerciveness or fraudulence of Allen's proposal) the blackmail agreement was invalid and therefore did not actually transfer Wilde's

fraudulence of blackmail are distinct ways of wronging the target. Thanks Grant Lamond for showing the need to clarify this point.

${ }^{88}$ See supra, note 26. 
authority ${ }^{89}$ It is wrong to attempt to usurp someone's deliberative authority. It is also wrong to try to convince someone that you have succeeded in taking control over his deliberative authority, even if your usurpation is unconvincing or unsuccessful. ${ }^{90}$

Third, the complex account can both justify criminal prohibitions on blackmail and avoid revisionist conclusions about blackmail's criminalization. Blackmail agreements are a conduit for fraud because they lack the mechanisms of mutual accountability that characterize valuable agreements. Fraud is a legitimate basis for

${ }^{89}$ Supra, note 31, To this point, I have assumed that the coerciveness of the blackmail proposal does not necessarily invalidate blackmail agreements. There is some merit to this assumption, since coercively imposed agreements (as well as other kinds of morally problematic agreements, such as unconscionable contracts and contracts with minors) are generally considered to be voidable by the party with the "power of avoidance," rather than void ab initio. See Perillo \& Murray, supra note 26, §1.6; Hamish Stewart, A Formal Approach to Contractual Duress, 47 U. ToRonTo L.J. 175 (1997). In other words, the offeror who acts wrongfully (e.g., the blackmailer) cannot enforce the agreement against the offeree, but the offeree (e.g., the target) can enforce the agreement against the offeror.

However, suppose that this assumption is incorrect and that, as some would argue (see supra note 28), the coerciveness of the blackmail proposal is sufficient to render any resulting agreement invalid. Even so, there is still a stench of fraud that makes the blackmailer's proposal different from other kinds of coercive proposals. If blackmail agreements are void ab initio, then proposing a blackmail agreement amounts to what Scott Anderson calls a "bluff threat," or an "issuance of a demand/threat by someone who lacks the power to execute that threat, and who knows that he lacks it." Scott Anderson, Of Theories of Coercion, Two Axes, and the Importance of the Coercer, 5 J. MoraL. PHIL. 394 (2008), at 418. Bluff threats seem to be both coercive and fraudulent - that is, they are wrong in exactly the same way that blackmail is wrong under the complex account. If blackmail agreements are invalid ab initio, then the blackmailer proposes to create a relationship that is (in virtue of his making the proposal) both legally and logically impossible. This proposal counts as fraud under the notion of valueless fraud articulated above. Therefore, even if the coerciveness of any blackmail proposal renders every resulting blackmail agreement void ab initio, the complex account can still capture wrong-making features of blackmail that other coercion-based views leave out. Thanks to Niko Cornell and Brian Berkey, among others, for prompting this discussion.

${ }^{90}$ See Anderson, Enforcement Approach, supra note 14, at 7-8 (articulating the "enforcement" notion of coercion, on which "coercive acts may affect indefinitely many of a coercee's activities some particular activity or activities, or none"). 
criminalization, as even libertarians who otherwise advocate for decriminalizing blackmail should concede.

Furthermore, the complex account provides a clean way to explain why blackmail should be criminalized whereas similarly coercive types of hard economic transactions should not. ${ }^{91}$ Hard economic transactions do not necessarily involve fraud in the way that blackmail does. The target of a hard economic transaction can formally enforce the terms of an agreement against the proposer who does not live up to her end of the bargain. Less formally, the target can hold the proposer to account by publicizing the proposer's perfidy to others. However, the target of informational blackmail can neither legally enforce the agreement against the blackmailer nor publicize the agreement without destroying its value.

In sum, the complex account can explain why blackmail should be criminalized, why there is a direct link between blackmail's wrongfulness and the legitimacy of its criminal prohibition, and why blackmail differs from hard (but licit) economic transactions.

The complex account can also reach the most plausible conclusions in Wilde's case and the variations discussed above. In Wilde's actual case, Allen behaved wrongfully because his proposal unjustifiably attempted to usurp Wilde's deliberative authority and because the agreement that Allen proposed would have lacked value for Wilde. If, as in Wilde1, Allen's proposal had led to an agreement with Wilde, then Allen would have committed a greater moral transgression than in real life. Allen would have attempted to usurp Wilde's deliberative rights by making the proposal. If Wilde had

${ }^{91}$ Supra, notes $43-45$. 
entered into the agreement, then Allen would have either successfully usurped Wilde's deliberative authority or (if the agreement was void ab initio) convinced Wilde that this usurpation succeeded.

In Wilde2, Allen is committed to opportunistic renegotiation at the time of formation. His behavior in this scenario would lack two hallmarks of value-Allen would lack a commitment to live up to his obligations, and Wilde would have no way to hold Allen accountable. Therefore, although Allen attempts to defraud Wilde in both Wilde1 and Wilde2, Allen's lack of commitment makes the agreement in Wilde2 fraudulent in a way that the agreement in Wilde1 might not be.

The complex account can also appreciate why Allen's conduct in Wilde3 would be wrongful. Even if Allen's proposal were welcomed by Wilde (and so perhaps not a frontal assault on Wilde's deliberative authority) and Allen were committed to refraining from disclosure and renegotiation, Wilde could not simultaneously hold Allen accountable and preserve the value of their agreement. The agreement proposed by Allen would lack the value characteristic of agreements for Wilde. Therefore, Allen's proposal is fraud.

Finally, it might be objected that my defense of the complex account aims to prove too much. If the fraudulence of blackmail agreements is sufficient to establish that blackmail is wrong and should be criminalized, then why should we favor a complex explanation in the first place? Rather than seeing the wrongfulness of blackmail in terms of both fraudulence and coercion, why not stop with the former?

Ignoring coercion undersells why blackmail is morally objectionable. On the simple account, both coercion and fraud can be seen as efforts to "take control over what 
is properly within [the target's] legitimate domain of judgment or action." 92 However,

coercion seems to be a more serious infringement of someone's deliberative authority and thus a greater wrong. In general, crimes that coercively impose harms or losses are more widely criminalized and more harshly punished than those that impose similar harms or losses through fraud. ${ }^{93}$ Perhaps the explanation for this discrepancy is that although both coercion and fraud violate someone's deliberative authority, the target of coercion is made to know that her deliberative rights are impinged while they are being impinged, whereas the target of fraud is not necessarily privy to her own domination.

92 Shiffrin, supra note 85 , at 216.

${ }^{93}$ For example, rape can involve both coercion (when the perpetrator "compel[s] the victim by threat of nonphysical harm sufficient to overwhelm the reasonable person") and fraud (when a perpetrator "obtain[s] sex by fraud or deception"). Russell Christopher \& Kathryn Hope Christopher, The Paradox of Statutory Rape, 87 IND. L.J. 505 (2012), at 532-535. In many jurisdictions only fraud related to the core nature of the sexual act is held to negate a target's consent to sex; other kinds of fraud (e.g., related to characteristics of the perpetrator) "are deemed as seller's puffery and thought too trivial to warrant rape liability." Id. at 534-535. By contrast, the vast majority of U.S. states criminalize at least some sexual acts in which a target's consent is obtained in the wake of a coercive proposal by another. See Patricia Falk, Rape by Fraud and Rape by Coercion, 64 BROOK. L. REV. 39 (1998), at 102 n. 309 (contending that forty jurisdictions have "at least one criminal provision outlawing the abuse of a position of power to obtain sexual intercourse"). Moreover, in some jurisdictions that criminalize both rape by coercion and rape by fraud, the former is a more serious offense than the latter. Compare CAL. PenAl CODE $\$ 266$ (2015) ("[E]very person who, by any false pretenses, false representation, or other fraudulent means, procures any female to have illicit carnal connection with any man" is punishable by imprisonment of up to one year) with CAL. PENAL CODE §261(a)(2) (2015) (rape is, inter alia, sexual intercourse accomplished "against a person's will by means of . . . duress," defined as "a direct or implied threat of force, violence, danger, or retribution sufficient to coerce a reasonable person of ordinary susceptibilities to perform an act which otherwise would not have been performed, or acquiesce in an act to which one otherwise would not have submitted," and is punishable by imprisonment up to eight years). 


\section{CONCLUSION}

Much of what is wrong with blackmail lies in the ways that the blackmail proposal coerces the target. Yet existing coercion-based accounts neither explain why noncoercive blackmail proposals are wrongful nor fully justify blackmail's criminalization. These gaps can be filled by the complex account, which construes blackmail as an effort to coerce and/or defraud the target. Because I use Shaw's simple account to demonstrate these points, my most immediate conclusion is narrow: a proponent of Shaw's simple account should accept the complex account as a friendly amendment.

More broadly, any defender of a coercion-based view can and should also

embrace the complex account. Advocates of such views can continue to see coercion at the heart of what makes blackmail wrong, explaining why, ceteris paribus, blackmail is morally worse than noncoercive attempts to defraud someone. Yet the complex account provides a further insight: the fraudulence of blackmail agreements explains why blackmail is more seriously wrong and more legitimately criminalized than coercive proposals that do not involve fraud.

Take the example of price gouging, a type of "hard economic transaction" that is linked in infamy with blackmail but is not uniformly criminalized. In the typical pricegouging case, the seller takes advantage of the buyer's desperate situation (sometimes, a situation caused by a natural disaster) to charge a higher-than-usual price for a critical good, such as an emergency power generator. On some views price gouging is coercive, ${ }^{94}$ and on other views it is not. ${ }^{95}$ Assume, for the sake of argument, that price gouging can be coercive. Even so, this practice is different from blackmail in one important respect. The target of price gouging at least receives the value characteristic of agreements. If the generator does not work, the seller does not deliver it, or the seller returns later in the day

\footnotetext{
${ }^{94}$ See, e.g., Julius, supra note 14, at 369-372.

${ }^{95}$ See, e.g., Matt Zwolinski, The Ethics of Price Gouging, 18 Bus. ETHICs Q. 347 (2008), at $354-356$.
} 
to raise the price, then the buyer has formal remedies (like pursuing a refund or legal redress) or viable informal options (like sharing the news of the seller's treachery with others). ${ }^{96}$

The same is not true in cases of blackmail. The target formally and practically lacks the power to hold the blackmailer to his or her end of the deal. Yet this kind of power is at the heart of what makes agreements valuable. Thus focusing on coercion undersells what is wrong with blackmail. Blackmail is both worse and far less controversial to criminalize than other kinds of transactions (like price gouging) that are arguably just as coercive.

${ }^{96}$ Similar reasoning distinguishes blackmail from other putatively coercive transactions
such as unconscionable contracts and so-called "unconstitutional conditions" cases. Unconscionable contracts are agreements whose "terms are seriously one-sided, overreaching, exploitative, or otherwise manifestly unfair." Shiffrin, supra note 85, at 205. Courts have latitude to decline to enforce unconscionable contracts. $I d$. Yet the party who is offered an unconscionable bargain (or, in the case of procedural unconscionability, unconscionably offered a bargain) is better off than the target of blackmail in at least one way: unlike the target of blackmail, the target of an unconscionable offer realizes some of the value characteristic of agreements. She can, for example, sue an offeror who fails to perform as bargained for.

Cases of "unconstitutional conditions" involve "government offers to provide a gratuitous benefit conditioned on the offeree's waiver of a constitutional right." Mitchell Berman, Coercion without Baselines: Unconstitutional Conditions in Three Dimensions, 90 GEO. L.J. 1 (2001), at 2. Berman notes that despite broad scholarly agreement that at least some such conditional offers are legitimate and others are not, "there is no consensus regarding whether and why any particular proposition of this form should pass muster." Berman, Blackmail, supra note 1, at 88 . These doctrinal debates aside, the complex account suggests that "unconstitutional conditions" cases differ from blackmail cases in at least one important respect. Unlike the target of blackmail, a state that accedes to a condition that is ex hypothesi coercively imposed by the federal government (e.g., expanding its Medicaid eligibility in order to receive federal funds) at least realizes the value characteristic of agreements. It can, for example, sue if the federal government does not actually provide the funds or services referenced in the proposal. 
The broadest implication of my analysis is that any account of what makes blackmail wrongful should scrutinize both the blackmail proposal and the blackmail agreement. Focusing only on the wrong-making features of the blackmail proposal obscures why some tokens of blackmail are wrongful. This strategy also creates unnecessary difficulties for explaining why blackmail is legitimately criminalized whereas functionally equivalent proposals are not. By contrast, an account that analyzes both the blackmail proposal and the blackmail agreement can avoid these difficulties. Thus, regardless of whether one accepts the complex account, a full explanation of what is wrong with blackmail should have this kind of complex structure.

The blackmailer proposes to sell the target shelter from a coming storm. But the storm is of the blackmailer's own making. The shelter provides no protection and it just might make things worse. There are two wrongs here, rather than one.

\section{APPENDIX}

In this appendix, I contend that Mitchell Berman's evidentiary theory of blackmail faces the same difficulties as Shaw's simple account. Here, too, the complex account should be taken as a friendly amendment, one that helps to resolve otherwise daunting explanatory challenges.

Here is a brief summary of Berman's evidentiary theory. A blackmail proposal references the blackmailer's (B's) future X-ing, which, if done, would harm the target (T) ${ }^{97}$ Despite this prospective harm, X-ing might or might not be permissible, depending (inter alia) on why B Xes or what B believes about X-ing when he does it. ${ }^{98}$ According to the "wrongful pressure" notion of coercion that Berman utilizes, B's proposal is

\footnotetext{
${ }^{97}$ Berman, Blackmail, supra note 1, at 71.

${ }^{98} I d$. at 68 .
} 
wrongfully coercive when (i) the X-ing it references would, if completed, be wrongful and harm T; and (ii) issuing the proposal exerts pressure on T's will or liberty to reject it. ${ }^{99}$ B's making a blackmail proposal provides strong evidence that any future X-ing by B would not be done for good reasons or would be based on illicit beliefs, and so would be wrongful. ${ }^{100}$ Therefore, B's making the proposal provides strong evidence that any future X-ing by B would (under Berman's definition) be coercive. If it is wrongfully coercive for B to $\mathrm{X}$, then it is wrongful for B to propose to do X. ${ }^{101}$

Assume for the sake of argument that the evidentiary theory is both valid and sound. Even so, it faces each of the difficulties that Shaw's simple account does. For example, the evidentiary theory cannot respond to the ratification objection, the idea that the target's entering into the blackmail exchange can (under certain circumstances) obviate the objectionable features of the blackmail proposal. Because the evidentiary theory explains the wrongfulness of blackmail entirely in terms of the blackmail proposal, considerations related to the blackmail agreement are irrelevant to its account of why blackmail is wrong.

Perhaps a proponent of the evidentiary theory might simply deny that there is any need to grapple with the ratification objection in the first place. It might be seen as

\footnotetext{
${ }^{99}$ This notion is a combination of how Berman defines wrongfully coercive proposals (Berman, Normative, supra note 14, at 55) and his contention that coercion operates by exerting pressure on the target's "freedom to choose otherwise" (id. at 53; Berman, Blackmail, supra note 1, at 66). It is unclear whether Berman sees the connection between the proposed X-ing and the pressure that operates on $\mathrm{T}$ as conceptual (i.e., where $\mathrm{X}$-ing would wrongfully harm $\mathrm{T}$, it exerts pressure on $\mathrm{T}$ by definition) or as contingent (i.e., that many prospective $\mathrm{X}$-ings tend to exert pressure on Ts).

${ }^{100}$ Berman, Blackmail, supra note 1, at 68.

${ }^{101}$ Id. at 38.
} 
obvious that in the typical blackmail proposal, the target's entering into the agreement does not or cannot ratify the wrong-making features of the proposal. ${ }^{102}$ Yet this response would be controversial, and it requires an independent defense. There is a big difference between contending that the typical blackmail agreement does not cleanse the objectionable features of the blackmail proposal and contending that no blackmail agreements could have this effect. It seems possible to accept the former proposition while denying the latter. ${ }^{103}$ Berman concedes that some promises made in the wake of coercive proposals can bind the parties, ${ }^{104}$ so it would be difficult for him also to declare that all blackmail agreements are obviously invalid. Establishing whether the creation of the blackmail agreement can alter the wrongfulness of the blackmail proposal requires analyzing the blackmail agreement in isolation from the blackmail proposal. Because the evidentiary theory construes the wrongfulness of blackmail exclusively in terms of the blackmail proposal, it lacks the resources to perform this analysis.

The evidentiary theory also has difficulty accounting for the compounding effect, or the notion that the blackmailer's actions can be both more coercive and worse when

${ }^{102}$ At times, Berman seems to have both advanced this position and rejected it. Compare Berman, Evidentiary Theory, supra note 1, at 852 ("[V]ictims of blackmail, just as much as victims of holdups, are likely to view the threatener's proposal as a 'threat,' not an 'offer,' and to experience themselves as acting under duress," such that their "acquiescence" is not "voluntary' in a sense sufficiently robust to counsel against societal interference with his purported transactional autonomy") with Berman, Normative, supra note 14, at 70 (the notion that a promisor "simply has no obligation, even prima facie, to honor a promise" made in response to "wrongful coercion" is "not a convincing position").

103 See, e.g., Joseph Millum, Consent under Pressure: The Puzzle of Third Party Coercion, 17 ETHICAL THEORY \& MORAL PRAC. 113 (2014), at 114.

${ }^{104}$ Berman, Normative, supra note 14, at 68-69 (contending that the coerciveness of a proposal that leads to an agent's promising is insufficient to establish that the agent is excused from keeping her promise). 
the blackmail agreement is consummated than when the proposal is rejected. By its own lights, the evidentiary theory should see the compounding effect as significant. On the evidentiary theory, coercive proposals are objectionable to the extent that they exert wrongful pressure on their targets. Holmes's suggestion that Milverton the blackmailer squeezes his targets "until he has drained them" suggests that the consummation of a blackmail agreement increases the opportunities for the blackmailer to pressure the target. Further, the blackmailer's squeezing the target provides even better evidence than his making the proposal that any eventual X-ing by the blackmailer would be based on illicit motives or beliefs and therefore would be wrongful under the evidentiary theory. Thus the advocate of the evidentiary theory should accept that the compounding effect exists and is troubling: regardless of their validity, blackmail agreements provide more avenues for pressure and better evidence of wrongfulness than do blackmail proposals.

Here, too, the evidentiary theory lacks analytic resources. The evidentiary theory's focus on the blackmail proposal prevents it from analyzing these wrong-making features of the blackmail agreement. Yet these features seem to be important aspects of why blackmail is wrongful.

Berman's evidentiary theory also does not provide a compelling case for criminalizing blackmail. Berman contends that blackmail may legitimately be criminalized as a form of theft. ${ }^{105}$ Yet he does not extensively argue for this conclusion, and any theft-based case for criminalizing blackmail seems open to a host of

${ }^{105}$ Berman, Blackmail, supra note 1, at 72. 
objections. ${ }^{106}$ In any event, each of the difficulties regarding blackmail's criminalization that confronts the simple account applies at least as strongly to the evidentiary theory. ${ }^{107}$

First, the evidentiary theory's case for criminalizing blackmail is potentially illiberal. ${ }^{108}$ If blackmail is criminalized but other kinds of information releases with exactly the same objectionable features cannot be, then it follows that criminal liability for the same combination of behavior and mental states can vary based solely on the motivations of the actor. This prospect is difficult to reconcile with liberal theories of criminalization, which do not allow the criminal status of an action to vary based solely on the motives of the actor. ${ }^{109}$ It is also contrary to extant criminal law, which does not make this distinction. ${ }^{110}$

${ }^{106}$ For example, the blackmail-as-theft argument for criminalization does not automatically explain why blackmail is an inchoate crime. Someone is guilty of theft only if he obtains possession or control over the victim's property. See Rivlin, supra note 28, at 419. Yet blackmail is a crime regardless of whether the blackmailer ever takes possession or control over any of the target's property.

The blackmail-as-theft argument also begs the question about whether blackmail agreements are valid. If, under certain circumstances (such as those described in Wilde3) blackmail agreements are valid, then the blackmailer's acquiring money as part of the exchange is not theft by the blackmailer, so much as performance by the target. Characterizing blackmail as a form of theft therefore presupposes that blackmail agreements are invalid and thus renders blackmail agreements central to justifying blackmail's criminalization.

${ }^{107}$ Moreover, unlike Shaw, who analyzes the moral wrongfulness of blackmail in isolation of whether blackmail should be criminalized, Berman sees the wrongfulness of blackmail as a premise in an argument for why blackmail should be criminalized. See Berman, Blackmail, supra note 1, at 40. Therefore any tendency toward abolitionism counts as an internal criticism of the evidentiary theory.

${ }^{108}$ See Shaw, supra note 1, at 196.

${ }^{109}$ See supra note 41.

${ }^{110}$ Berman posits that "there is no reason ... that an explicit description of [the defendant's] motivation cannot be imported into a definition of the conduct to be criminalized" under blackmail statutes. Berman, Evidentiary Theory, supra note 1, at 
Second, the evidentiary theory cannot provide a principled basis for criminalizing blackmail while decriminalizing "hard commercial transactions" involving the same prospect of wrongful pressure that blackmail does. Berman advances two different strategies for making this distinction under the evidentiary theory, one based on the target's interests regarding the X-ing referenced in the proposal, ${ }^{111}$ and the other based on

843-844. This statement concedes that no existing blackmail statute allows for liability to vary based solely on the motivations (rather than the actions and mental states) of the blackmailer. Berman uses the example of "good faith" defenses to charges of criminal libel to illustrate the possibility of liability that varies based solely on motivation. $I d$. at 844. However, this example is inapt, since the Supreme Court has rejected the notion that the legal status of information disclosures regarding public officials may vary solely based on the discloser's motivations. See Garrison v. Louisiana, 379 U.S. 64, 73-74 (1964); see also Hustler Magazine, Inc. v. Falwell, 485 U.S. 46, 53 (1988). Moreover, although every U.S. state criminalizes blackmail, the majority of states either lack a criminal libel statute or have had their statutes declared unconstitutional - in many cases, precisely because they allow for the possibility that a defendant's liability could vary based solely on his motives. See David Kohler, Forty Years after New York Times v. Sullivan: The Good, the Bad, and the Ugly, 83 OR. L. REV. 1203 (2004), at 1232-1233.

Aside from criminal libel, Berman does not provide any other example of a crime for which liability for the same act and mental state combination could vary based solely on the motives of the defendant. See also Peter Westen, Why the Paradox of Blackmail Is So Hard to Resolve, 9 OHIO ST. J. CRIM. L. 585 (2012), at 629 (concluding that published blackmail cases reflect the principle that "a bad motive, with which a person knowingly performs an otherwise [legal] act, can[not] render [the person's] conduct [illegal]").

${ }^{111}$ In earlier work, Berman contends that the X-ing implicated in informational blackmail would set back legally protectable interests of $\mathrm{T}$ (namely, her reputation and emotional well-being), whereas the X-ing implicated in "hard commercial transactions" implicates interests that are not legally protected. Berman, Evidentiary Theory, supra note 1, at 856.

Although this discrepancy applies to the specific examples that Berman considers, it does not generalize to all cases of "hard commercial transactions." For many "hard commercial transactions" involving legally protectable or protected interests (e.g., someone's health or reputation or freedom), hard bargaining is nevertheless licit. A surgeon can make a firm, take-it-or-leave-it proposal about her rate to perform a surgery without committing blackmail. So can a lawyer regarding her rate for representing a client. If so, then blackmail cannot be distinguished from "hard commercial transactions" based solely on which interests are affected by the X-ing referenced in the proposal. 
the wrong-making feature that $\mathrm{X}$-ing manifests. ${ }^{112}$ For the reasons articulated in the previous two footnotes, neither of these strategies succeeds. Moreover, apart from whether either strategy succeeds on its own terms, Berman should not find either of them satisfactory. Berman concedes that each strategy yields the conclusion that some wrongfully coercive proposals constitute blackmail in the moral sense but should not be criminalized. ${ }^{113}$ Yet this concession conflicts with Berman's metatheoretical contention that the "moral wrongfulness" of blackmail must provide "a sufficient basis for [its] criminalization." 114

Third, the evidentiary theory's case for criminalization is revisionist in a way that Berman believes it should not be. As noted above, the evidentiary theory explains the wrongfulness of blackmail based on features of the X-ing referenced in the proposal, the beliefs and/or motivations of the blackmailer, and the prospect that the proposal will exert pressure on the target's will or liberty. On the other hand, the blackmail-as-theft argument says that blackmail is appropriately criminalized because any transfer of money

${ }^{112}$ In later work, Berman contends that hard commercial bargains and blackmail involve different kinds of wrongs, rather than different kinds of harms. Berman argues that blackmail proposals involve coercion, whereas hard commercial bargains involve the "less serious" wrong of exploitation and, as a result, provide a "less secure basis" for criminalization. See Berman, Blackmail, supra note 1, at 74. Berman seems to misconstrue the evidentiary theory here. Contra Berman, "hard commercial transactions" are coercive under the evidentiary theory because they involve an action that if completed would both be wrongful and would harm someone. Exploitation is a wrong-making feature of an action. Therefore, "hard commercial transactions" propose an action that if carried out would commit a wrong (i.e., the wrong of exploitation) and harm the target. Therefore they should be classified as coercive under the evidentiary theory.

${ }^{113}$ See, e.g., Mitchell Berman, Meta-Blackmail, supra note 64, at 798 n. 37 (noting that Murphy's "Baseball" case involves a morally coercive proposal that for "practical imperatives, in our current society" we do not criminalize).

${ }^{114}$ Berman, Normative, supra note 14, at 82. 
or goods from $\mathrm{T}$ to $\mathrm{B}$ in the wake of the proposal would constitute a form of theft by $\mathrm{B} .^{115}$ The blackmail-as-theft argument therefore makes no essential reference to the features that, according to Berman, make blackmail wrong (such as the nature of X-ing, B's beliefs and/or intentions, or the pressure experienced by T). ${ }^{116}$ Thus the evidentiary theory's case for criminalizing blackmail conflicts with what Berman contends is a desideratum of any blackmail theory, namely that its explanation of why blackmail is illegal should also help explain why blackmail is immoral. ${ }^{117}$

In sum, the evidentiary theory is abolitionist or revisionist regarding the criminalization of blackmail in each of the ways that the simple account is: its argument for legally prohibiting blackmail is difficult to reconcile with liberalism, does not cleanly distinguish blackmail from (licit) hard bargaining, and is divorced from the explanation of why blackmail is immoral.

Berman's evidentiary theory and Shaw's simple account share many structural features and differ mainly in the notion of wrongful coercion that they utilize. Yet the same difficulties apply to the evidentiary theory as to the simple account. These difficulties, then, would seem to arise out of structural features shared by the two theories rather than out of the disparate notions of coercion that they utilize. In particular, both the evidentiary theory and the simple account construe the wrongfulness of blackmail in

${ }^{115}$ Berman, Blackmail, supra note 1, at 72-73.

${ }^{116}$ Some theorists use the blackmail-as-theft argument to explain why blackmail is immoral. See, e.g., GREEN, supra note 51, ch. 17; Rivlin, supra note 28, at 419. However, Berman contends that this blackmail-as-theft strategy does not address the "puzzle of moral blackmail" that is his main focus. Berman, Blackmail, supra note 1, at 53.

${ }^{117}$ Berman, Blackmail, supra note 1, at 40 ("[W]e should not be satisfied" with explanations of why blackmail should be criminally prohibited "that do not also shed light on the puzzle of moral blackmail"). 
terms of the blackmail proposal. If the analytic focus of the evidentiary theory were broadened to include the blackmail agreement, then each of difficulties identified here might be avoided in one fell swoop.

One way to achieve this goal is to incorporate Berman's evidentiary theory into the complex account. On this combination, the blackmail proposal would be coercive because it would provide good evidence that any X-ing by the blackmailer would wrongfully harm the target, and the agreement referenced in the proposal would also constitute an attempt to defraud the target.

Integrating the evidentiary theory into the complex account would improve the former in several ways. This modification would provide ample grounds for responding to each of the difficulties described above. In response to the ratification objection, Berman could say that because the blackmail agreement is fraudulent, the target's entering it does not affect the significance of the wrongful pressure occasioned by the blackmail proposal. Likewise, Berman could offer a ready explanation for the compounding effect: consummated blackmail agreements are worse than unconsummated proposals because, although both types of proposals involve both the prospect of wrongfully harming the target, the former also defrauds the target. ${ }^{118}$ For the reasons noted above, ${ }^{119}$ the fraudulence of the agreement at the heart of the blackmail proposal provides a sufficient basis for criminalizing blackmail, as well as a basis for

${ }^{118}$ On the evidentiary theory, the wrong involved in coercion (wrongfully putting pressure on another's liberty to do otherwise) is distinct from the wrong involved in fraud. Therefore, a complex account that incorporates the evidentiary theory does not allow for an explanation by subsumption in the same way that a version based on Shaw's simple account does. See supra note 87.

119 See the discussion of why fraudulence is a sufficient basis for criminalizing blackmail, supra at Section II.A.1 and II.B. . 
distinguishing blackmail from "hard commercial transactions" that even the abolitionist

could abide. Finally, incorporating the evidentiary theory into the complex account would capture several desiderata of a theory of blackmail that Berman identifies but that the evidentiary theory fails to capture. ${ }^{120}$

Thus the advocate of the evidentiary theory can and should accept the complex account as a friendly amendment.

${ }^{120}$ As noted above, Berman contends (a) that a theory of blackmail should draw internal connection between the explanation of why blackmail is immoral and why it is illegal and (b) that its explanation of why blackmail is immoral should also be sufficient to explain why it is criminalized. The evidentiary theory does not satisfy either of these desiderata. For Berman, the coerciveness of the blackmail proposal explains why blackmail is wrongful and (on the blackmail-as-theft argument) the fact that blackmail is theft explains why it is illegal. By contrast, the complex account can capture both of these desiderata: the fact that blackmail involves fraud would provide a common basis for seeing blackmail as both immoral and worthy of criminalizing.

Here is a further respect in which the complex account improves on the evidentiary theory. By construing the case for criminalization in terms of fraud, the complex account can "persuade committed libertarians . . . based on libertarian premises" that blackmail should be prohibited, whereas (as Berman concedes) the evidentiary theory cannot do so. See Berman, Blackmail, supra note 1, at 58. 